\title{
Osmanlı Klasik Dönem Mimarisinde 17. Yüzyıl Eserlerinden Sultan Ahmed Külliyesi'nde Ahşap Malzeme Kullanımı*
}

\author{
Aliye Öten ${ }^{* *}$
}

\begin{abstract}
$\ddot{\mathbf{O} z}$
Sultan Ahmed Külliyesi, 17. yüzyıl Osmanlı mimarisini temsil eden sayılı külliyelerden biri, hatta yapı topluluğu ve alan bazında en büyügüdür. Osmanlı mimarisinde Mimar Sinan ve öğrencilerinin geliştirdiği klasik dönemin son eserlerinden biridir. Aynı zamanda Osmanlı mimarisinde farklı ebatların denendiği ve külliye sisteminden vazgeçildiği yeni bir dönemin hazırlık aşamasındaki eserlerindendir. Bu yüzden 17. yüzyılı tanımlayan eserlerin Osmanlı mimarisinin bütününü kavrama açısından iyi anlaşılabilmesi ve tercihlerinin iyi değerlendirilmesi gerekmektedir. Bu durum dönemin devlet teşkilatı ve inşa görevlilerinin eliyle kaleme alınmış birinci derece kaynak durumundaki arşiv belgelerinin incelenmesini gündeme getirmektedir. Sultan Ahmed Camii merkezli külliye ile ilgili bilgilere; rûznamçe, vâridât ve masârif defterleri gibi kaynakların taranmasıyla ulaşılabilir. İnşa sürecinde çalışanlar, kullanılan malzemeler, inşaat aşamaları, organizasyon vb. pek çok konuda arşiv kaynaklarından bilgi almak mümkündür. Bu çalışmada inşa evrakında yer alan malzemelerden ahşap üzerinde durularak; kaynakları, cinsleri, ustaları, masrafı ve sanatları hakkındaki bilgiler ele alınarak incelenmiştir.
\end{abstract}

Anahtar Kelimeler: Sultan Ahmed Külliyesi, ahşap malzemeler, ahşap malzeme kullanımı

* Bu araştırma Marmara Üniversitesi Bilimsel Araştırma Projeleri Komisyonu'nun SOSC-DRP-120514-1290 proje no'suyla desteklenmiş olup proje sonuçlarının bir bölümünü oluşturmaktadır. Bu çalışmanın gerçekleştirilmesine ilgi, bilgi ve emeğiyle destek olan çok kıymetli Prof. Dr. Aziz Doğanay'a sonsuz teşekkürlerimi sunarım.

** Dr., Diyanet İşleri Başkanlığı, İstanbul/TÜRKIYY, aliyeakturk@gmail.com ORCID 0000-0003-1753-831

DOI:

Makale Gönderim Tarihi: 23.12.2019 - Makale Kabul Taruhi: 11.08.2020

Belleten, Nisan 2021, Cilt: 85/Sayı: 302; 53-94 


\title{
The Use of Wooden Materials in Sultan Ahmed Complex, a $17^{\text {th }}$ Century Artifact in Ottoman Classical Period Architecture
}

\begin{abstract}
The Sultan Ahmed Complex is one of the few complexes representing the $17^{\text {th }}$ century Ottoman architecture, and is even the largest in terms of building community and area. It is one of the last works of classical period developed by Mimar Sinan and his students in Ottoman architecture. At the same time, it is one of the works in the preparation stage of a new era in which different dimensions were tried in Ottoman architecture and the complex system was abandoned. Therefore, the works that define the $17^{\text {th }}$ century should be understood in terms of understanding the whole of Ottoman architecture and their preferences should be evaluated well. This situation brings up the examination of the archival documents as first hand source which were written by the state organization and construction officials of the period. Sultan Ahmed Mosque-based complex information can be accessed by scanning resources such as rûznamçe, vâridât and masârif books. It is possible to get information from archival sources on many subjects such as construction workers, used materials, construction stages, organization, etc. In this study, with emphasis on wood used, through archival documents; the information about sources, genres, masters, costs and arts has been examined.
\end{abstract}

Keywords: Sultan Ahmed Complex, wood materials, use of wood materials

\section{Giriş}

Sultan Ahmed Camii 17. yüzyıl başında inşa edilmiş olup yüzyllın iki büyük külliyesinden birinin ana binasını teşkil eder. Klasik dönem İstanbul üslubunun son eserlerinden biri olan Sultan Ahmed Camii'nin, banisi Sultan Ahmed Han-1 evvel ve mimarı Sedefkâr Mehmed Ağa'dır. Osmanlı mimarisinin yüksek üsluba ulaştığı 16. yüzyıl eserleri başta Süleymaniye Camii ve Külliyesi olmak üzere araştırmacılar tarafindan yoğun olarak incelenmiştir. 17. yüzyıl Osmanlı mimarisi ise araştırmacılar için hala gizemini korumaktadır.

Osmanlı mimarisini anlamaya yarayacak birinci derece kaynakların başında, devlet tarafindan yaptırılan yapılar için düzenlenen inşaat defterleri ile onarılacak yapıların onarım masrafını belirlemek için önceden hazırlanan keşif defterleri gelmektedir. Bu defterler, her ne kadar malî nedenlerle hazırlanmış olsa da, yapım sürecindeki malzemenin ücret, ebat, menşei; işçi sınıfi, sayısı, ücreti ile ilgili gelir ve harcamaların hesabının tutulduğu defterler olup, inşa kronolojisi ile ilgili önemli 
bilgiler vermektedirler. Rûznamçe, vâridât ve masârif, keşif gibi türleri bulunan bu defterlerde hazineden gelen paranın, kime teslim edildiği, nerelere, kimin talebiyle sarf edildiği gibi inşa organizasyonu ile ilgili bilgilerle birlikte malzeme türü, adeti, birim fiyatı, nereden geldiği ve ne zaman alındığı gibi çok detaylı bilgiler yer almaktadır. Bu nedenle bu belgeler mimarlık tarihine de ışık tutmaktadır.

$\mathrm{Bu}$ defterlerdeki bilgilerden hareketle Osmanlı döneminde kullanılan inşaat malzemeleri, yapım teknikleri, inşa organizasyonu ve bunların tarih içindeki değişim süreci tespit edilebilir. Ayrıca Ayazma Camii, Süleymaniye Külliyesi, Sultan Ahmed Camii, Nuruosmaniye Camii inşa defterleri üzerine yapılan çalışmalarda olduğu gibi yapının inşaat aşamaları da belirlenebilmektedir ${ }^{1}$. Belgelerde yer alan ahşap malzeme genellikle cinsli, miktarı, ebadı, birim fiyatı ve toplam fiyatı belirtilerek listeler halinde verilmektedir. Osmanlı dinî mimarisini teşkil eden cami ve külliye gibi kârgîr yapıların inşa defterlerinde alımına rastladığımız büyük miktarlardaki ahşap malzeme, genellikle hatıl olarak temel ve duvar yapımında ve yapı iskelesinde kullanılmıştır².

Sultan Ahmed Camii'nin özellikle 'Mavi Cami' olarak tanınmasına neden olan zengin kâşî panolarını tamamlayan kalemişi tezyinatı ve hünkâr mahfilinde yoğunlaşan taş iş̧̧iliği kadar; ahşap işleri ve sedef kakma işçiliği tezyinat programında dikkati çekmektedir. Banisi sultan olan ve mimarı da özellikle sedefkârlıkta maharet sahibi bir sanatkârın çalıştığı bu yapida; pek çok usta ve sanatçı maharetlerini sergilemiştir. Bu çalışmada bahsi geçen görevli, usta ve ahşap yapı malzemeleri Sultan Ahmed Camii rûznamçe, vâridât ve masârif defterlerinde kaydedildiği şekilde tanıtılmaya çalışılacaktır.

\section{Ahşap Yapı Malzemeleri}

Ahşap yapı malzemelerinin genel adı olan kereste işiyle uğraşan esnafa keresteciyân denmektedir ve bu topluluk kethüda vb. unvan hiyerarşisine sahip bir

1 İlknur Aktuğ Kolay - Serpil Çelik, "Malzeme ve Teknoloji”, Bir Şaheser Süleymaniye Külliyesi, ed. Selçuk Mülayim, Ankara 2007, s. 138; Serpil Çelik, Mevcut Belgeler Işı̆ğnda Süleymaniye Külliyesinin Yaprm Süreci, İstanbul Teknik Üniversitesi Fen Bilimleri Enstitüsü Doktora Tezi, İstanbul 2001, s. 91; Ali Öngül, "Tarih-i Câmi-i Nuruosmânî”, Vakıflar Dergisi, S. 24, (1994), s. 127-145; Aliye Öten, Arşiv Belgelerine Göre Sultan Ahmed Kïlliyesi ve İņ̧ast, Marmara Üniversitesi Sosyal Bilimler Enstitüsü Doktora Tezi, İstanbul 2017, s. 546-684.

2 İlknur Aktuğ Kolay, "XVI. Yüzyılda Kullanılan Bazı İnşaat Malzemeleri ve Kullanım Yerleri”, 16. Yüzyllda Türk ve İslam Bilim ve Teknolojisi Sempozyum Bildiri Kitapçı̆̆r, İTÜ Mimarlık Fakültesi, İstanbul 1986, s. 72. 
organizasyon içindedir ${ }^{3}$. İstanbul'un fethinden itibaren keresteci, keserci, kiremitçi, kireççi, kutucu ve kâşîci gibi inşaya has görevliler ile birlikte; ehl-i hıref, neccâr, ırgat ve hamalların ücretleri cinsi ve ölçüsüyle ferman olunması 1640'lara kadar mimarbaşının görevi olmuştur. 1640 yllı itibariyle es'ar defterleri oluşturularak, inşa malzemeleri ve görevlileri hakkındaki ölçü ve fiyat standartları belirlenmiştir". Bu nedenle piyasada kullanılan kerestelerin belli ölçüleri olsa da, tarihi eserlerde kullanılan kerestelerin ebatlarının tespit edilebilmesi için mimarbaşıların ve bina eminlerinin defterlerinden ve vilayetlere gönderilen hükümlerin incelenmesiyle çıarılacak neticelere ihtiyaç vardır ${ }^{5}$.

Sultan Ahmed Camii'nin 01.05.1018/02.08.1609'da başlanan ve kubbenin kilitlenme başarısı sebebiyle 10 kurban kesildiği 30.09.1024/23.10.1615'e kadar süren inşası sürecinde pek çok ahşap malzeme alınmıştır ${ }^{6}$. Sultan Ahmed Külliyesi inşası sırasında iskele, iksa, temel ve duvar hatılları, temel kazıkları, çatı, pencere, kapı ve mobilyalarında ahşap malzeme kullanılmıştır. Sultan Ahmed Camii ve Külliyesi'nin inşa evrakında ceviz ağacı, elvâh-1 gürgen (gürgen levhalar), pedavra-i Sakarya, elvâh-1 Bahr-i Siyâh (Karadeniz levhaları), elvâh-ı bellût-1 Şilye/Şile (Şile pelit levhaları), elvâh-1 Ağva gibi çeşitleri bulunan kerestelerin alımı ve kullanımı ile ilgili çeşitli bilgiler yer almaktadır.

İnşa evrakında adı geçen ahşap malzemelerin bârûy-ı çûb, çûb-ı makaslık, kabza-i çûb-1 pereme, çûb-1 kazma, kürekhâ-i çûb, çûb-1 kiriş, çûb-i körpe, çûb-1 Rumeli-i harcî, elvâh, taban, verke, sütun gibi çeşitleri vardır. Ada-i cedîd, İznikmîd (İzmit), Midye, Karapürçek, Bahr-i Siyâh gibi yerlerden temin edilen 'kerestehâ-i mütenevvi'a' (çeşitli keresteler), Bâb-1 Hîme, Gümrük, Davudpaşa gibi iskelelerden hamallar ve arabalar vasıtasıyla inşa alanına nakledilmiştir. Kerestelerin Mimarbaşı Mehmed Ağa tarafindan seçilmesinden sonra, siparişi vermek, getiriliş şekline göre refakat etmek, inşa sahasına ulaştırmak ve inşa sahasına ulaştıktan sonra bekletilmesi veya kullanılmasında insiyatif sahibi olmak gibi konularda devreye Mehmed bevvâb, Mehmed keresteî, Hüsrev Halife gibi görevliler girmektedir.

Ahşap malzemenin önemli bir bölümü inşaat sırasında yapının içinde ve dışında kurulan iskelelerde kullanılmıştır. Yapıda inşa edilen çalışma iskelesi belirli

3 TS.MA.d 35-0-0, 29.08.1025/11.09.1616, v. 33.

4 Yaşar Yüceil, Osmanh Ekonomi-Kültür-Uygarlk Tarihine Dair Bir Kaynak Es'âr Defteri (1640 Tarihli), Türk Tarih Kurumu Basımevi, Ankara 1992, s. 16-17.

5 Celâl Esat Arseven, Sanat Ansiklopedisi, C II, Milli Eğitim Basımevi, İstanbul 1947, s. 1047.

6 TS.MA.d 35-0-0, 29.08.1025/11.09.1616, v. 3-216.

Belleten, Nisan 2021, Cilt: 85/Say1: 302; 53-94 
yüksekliklerde çalısma platformları oluşturulan bir konstrüksiyona sahiptir ve inşaatın ikinci senesinden sonra alınan ahşap malzeme beden duvarlarının üst kısmı ve örtü sistemi için gerekli olan iskelenin geri kalan kısmının yapımı içindir?

Osmanlı mimarisinde ızgara temel olarak tanımlanan temel yapım tekniğinde temel pabuçları şeklinde inşa edilen temel duvarı, içinde veya üzerinde ızgara şeklinde yerleştirilmiş ahşap hatılların bulunduğu yaklaş̧k $20 \mathrm{~cm}$ kalınlığında bir horasan tabakasının üzerine oturur ${ }^{8}$. Temelde temiz suyun bulunarak, temel kazma işleminin sonuna gelindiği bu aşamada inşa sahasına ulaşan bu Karapürçek levhalarının temel çukurunun iksasında toprağı tutan ahşap perdeyi oluşturması söz konusudur ${ }^{9}$.

Ana malzemesi taş ve tuğla olan Sultan Ahmed Camii’nde iskeleler kaldırılmış olduğundan; temeli gözlem imkanı da olmadığından; ahşabı ancak kapı kanatları, pencere ve dolap kapaklarında ve cami teşrifatında kullanılan mobilyalarda izleyebiliyoruz. $\mathrm{Bu}$ nedenle belgelerdeki tüm ahşap malzemenin veriler doğrultusunda yapılarda kontrol edilmesi mümkün olamamaktadır ${ }^{10}$. Fakat arşiv belgeleri, şahit olmadığımız ve izleyemediğimiz ahşap inşa malzemeleri ve hatta tamir malzemeleri hakkındaki tüm bilgileri sunmaktadır.

Arşiv belgelerine göre, Sultan Ahmed Külliyesi inşasında kullanılan ahşap yapı malzemelerinin, temin yerleri, temin süreci, alınan yerler, temin görevlileri, cins, ebat ve fiyat bilgileri ile ilgili detaylı bilgiler, 11.08.1018/09.11.1609 Pazartesi Karapürçek levhaların alınmasıyla başlar. Külliye inşa sürecinde İbrahim Paşa Sarayı Kasrı'nın inşa edildiği döneme rastlayan bu alımlar, kaplama amacıyla neccârlar tarafından kullanılmıştır. Cinsi ve ebadı verilmeyip sadece Karapürçek (Sakarya) ten geldiği bilgisi verilen bu levhaların, inşa sürecinin başında ve sadece İbrahim Paşa Sarayı için alınması ve kullanılması söz konusudur.

7 İlknur Aktuğ, "Ayazma Camisi İnşaat Defteri”, 9. Milletlerarası Türk Sanatlan Kongresi Bildiriler (2327 Eylül 1991 İstanbul), C I, T. C. Kültür Bakanlı̆ğ Yayınları, Milli Kütüphane Basımevi, Ankara 1995, s. 81.

8 H. Peynircioğlu - E. Toğrol - İ. H. Aksoy, "İstanbul'da Osmanlı Döneminde İnşa Edilen Camilerin Temelleri”, L. Uluslararası Türk-Islam Bilim ve Teknoloji Tarihi Kongresi 14-18 Eylül 1981. C III. İstanbul 1981, s. 39. İ. A. Kolay - A. Ersen, "Bir 15. Yüzyıl Yapısı Olan Tahtakale Hamaını'nda Uygulanan Bazı Yapım Teknikleri”, Taç Vakfi Yillıği, S. 1, İstanbul 1991, s. 26.

9 Aktuğ, "Ayazma Camisi İnşaat Defteri”, s. 9-90.

10 Kolay, "XVI. Yüzyılda Kullanılan Bazı İnşaat Malzemeleri ve Kullanım Yerleri”, s. 127. 
İnşa belgelerinde temelden kubbeye kadar pek çok aşamada ve pek çok yerde kullanılan sütun, çubuk, mertek, verke ve levhalar hakkında da detaylı bilgiler mevcuttur ${ }^{11}$. Külliyenin başta cami olmak üzere diğer unsurlarında kullanılan ahşap malzemelerin ağaç cinsleri, getirildikleri ve kullanıldıkları yerler hakkında verilen bilgileri bir araya getirdiğimizde tablo l'deki verileri elde etmekteyiz.

Tablo 1: BOA. D. 35 no'lu deftere göre Sultan Ahmed Külliyesi inşasında kullanılan ağaç cinsleri ve kullanıldıkları yerler.

\begin{tabular}{|l|l|l|l|l|}
\hline \multicolumn{5}{|c|}{ Sultan Ahmed Camï İnşasında Kullanılan Ahşap Malzeme Ağaç Çeşitleri ve } \\
Kullanıldıkları Yerler
\end{tabular}

11 Öten, agt., s. 239-285.

Belleten, Nisan 2021, Cilt: 85/Say1: 302; 53-94 


\begin{tabular}{|c|c|c|c|c|}
\hline Çam & $\begin{array}{l}\text { Verke, binar, } \\
\text { mertek }\end{array}$ & Taban Kirişi & Temel, bina & $?$ \\
\hline Gürgen & Verke, Elvâh & $\begin{array}{l}\text { Taban Kirişi, } \\
\text { Kaplama }\end{array}$ & Temel, bina & İznikmîd \\
\hline $\begin{array}{l}\text { Gülgen (Beyaz } \\
\text { Kayın) }\end{array}$ & Elvâh & & $\begin{array}{l}\text { Inşaat aletleri ve } \\
\text { toprak taşıma } \\
\text { arabaları }\end{array}$ & $\begin{array}{l}\text { İznikmîd } \\
\text { Ereğli } \\
\text { Esnaftan } \\
\text { alınmış } \\
\end{array}$ \\
\hline Kestane & Elvâh & Kaplama & $\begin{array}{l}\text { Pencere, dolap } \\
\text { kapağı, kapı } \\
\text { kanadı }\end{array}$ & $\begin{array}{l}\text { Satılmış } \\
\text { Kethüda'dan } \\
\text { alınmış } \\
\end{array}$ \\
\hline Abanoz & Çûb & Kaplama & $\begin{array}{l}\text { Pencere, dolap } \\
\text { kapağı, kapı } \\
\text { kanadı } \\
\end{array}$ & \\
\hline $\begin{array}{l}\text { Çûb-1 } \\
\text { cevherdârî }\end{array}$ & & & Tezyinat & \\
\hline Elvah-1 Sefîne & Muhtelif & & & ? \\
\hline Ahşab-1 köhne & & & & \\
\hline
\end{tabular}

Sultan Ahmed Cami merkezli külliye inşasında tablo 1'de görüldüğü üzere elvâh-1 kestane, verke-i siyâh-1 gürgen, elvâh-1 gürgen, verke-i çam, elvâh-1 karaağaç, sütûn-1 karaağaç, elvâh-1 findık, çûb-1 kızılcık, çûb-1 şimşir, elvâh-1 şimşir, tomruk-1 şimşir, elvâh-1 bellût-ı Şile (Pelit), tomruk-1 sanavber (Çam fistığı ağacı), elvâh-1 koz (ceviz), pedavra-i Sakarya ve çubuk-ı verdinar şeklinde adlandırılan ahşap malzemeler kullanılmıştır. İnşa evrakında kereste çeşitleri, yapıda kullanıldığı yer, ebat, kalite yahut geldiği yerle tanımlanarak kullanılmıştır. Fiyatı ve ebadı narhla belirlenmemiş olan ve özel üretilen ürünler hakkında detaylı bilgiler verilirken, narha tabi olan ürünlerin sadece adet ve ücreti yer almaktadır.

Ahşap yapı elemanlarına bakılacak olursa, terimlerin kökeninin farklılık arz ettiği görülür. Risale-i Mimariye'de "çubuk" ve "çûb" kelimeleri, Çubuk Türkçe ve Çûb Farsça olmak üzere aynı anlama gelmektedir ve dikdörtgen kesitli dikmeden ibarettir $^{12}$. Aynı eserin ileriki bölümlerinde çûb’un 17. yüzyılın ilk yarısı itibarıyla kereste olarak kullanıldığı belirtilmektedir. Bu yüzden 16. yüzyıl inşa evraklarında mertek, direk, pedavra, kazık, tirfil, ırgat, makara gibi isimlerle birlikte kullanılan

12 Cafer Efendi, Risâle-i Mimâriyye, haz. İ. Aydın Yüksel, İstanbul Fetih Cemiyeti, İstanbul 2005, s. 84. 
ve çeşitlilik arz eden çûb/çubuk teriminin ölçü birimi es'ar defterlerinde mevcut olduğundan Sultan Ahmed inşa evrakında yer almamaktadır ${ }^{13}$. Mesela pedavra ${ }^{14}$ ifadesini metin içinde değerlendirmek gerekirse; Sultan Ahmed Camii varidât ve masârif defterinde ${ }^{15}$ pedavra-i dirâz olarak geçen bu yapı malzemesinin, kiremit altı kaplaması, çatı kaplaması olarak kullanıldığı bilinmektedir ${ }^{16}$. Pedavra-i dirâz veya pedavra-i Sakarya şeklinde geçen bu malzemenin ebadı bildirilmemekte fakat himl ölçü birimi ile satın alınıp taşındığı belirtilmektedir ${ }^{17}$. Sultan Ahmed Camii rûznamçesinde çûb-1 makaslık, çûb-1 tirfil ${ }^{18}$, çûb-1 abanoz, çûb-1 şimşir, elvâh-1 çûb, çûb-1 cevherdârî, çubuk-1 harcî, çûb-1 bînar (bînar, bınar, pinar olarak geçen ahşap, kalın dört köşe kadranlardır ${ }^{19}$ ), çûb-1 çubuk-1 körpe, çûb-1 meyâne, tomruk-1 çûb-1 siyâh ve çûb-1 hurda şeklinde çeşitleri geçmektedir ${ }^{20}$.

Tablo 2: Sultan Ahmed Külliyesi inşasında kullanılan Çûb/çubuk çeşitleri ve ölçüleri.

\begin{tabular}{|l|l|l|l|l|l|l|}
\hline & Adet & $\begin{array}{c}\text { Tûlen } \\
\text { (Boy) }\end{array}$ & $\begin{array}{c}\text { Arzan } \\
(\text { En) }\end{array}$ & $\begin{array}{c}\text { Isbi } \\
\text { (Derinlik) }\end{array}$ & $\begin{array}{c}\text { Birim } \\
\text { fiyatı }\end{array}$ & \multicolumn{1}{|c|}{$\begin{array}{c}\text { Toplam } \\
\text { fryatı }\end{array}$} \\
\hline Çûb-1 makaslık-1 kemer & 761 & 7,5 zirâ $^{6}$ & 4 & 2,5 & 14 Akçe & 10.654 Akçe \\
\hline Çûb-1 makaslık & 622 & 6 & 4 & & 14 Akçe & 8.708 Akçe \\
\hline Çûb-1 makaslık & 450 & 7 zirâa $^{6}$ & 3 & 2 & 6 Akçe & 2.700 Akçe \\
\hline Çûb-1 tirfil & 46 & 6 zirâa $^{6}$ & & & 25 Akçe & 1.150 Akçe \\
\hline Tomruk-1 çûb-1 siyâh & 6 & $\begin{array}{l}14 \text { zirâ }^{6} \\
18 \text { ssbi }^{6}\end{array}$ & 48 & 8 & $\begin{array}{l}220 \\
\text { Akçe }\end{array}$ & 1.320 Akçe \\
\hline
\end{tabular}

13 İlknur Aktuğ Kolay, "Osmanlı Belgelerinde Yer Alan Bazı Ahşap Yapı Malzemesi Üzerine Düşünceler”, Sanat Tarihi Defterleri, S. 10 (2006), s. 30-31.

14 Köknar ve ladin ağaçlarından elde edilen, çatı örtüsü olarak kullanılan ince tahta, balar. https:// sozluk.gov.tr/?kelime=PEDAVRA

15 BOA, D.00211.001.00.

16 Kolay, "Osmanlı Belgelerinde Yer Alan Bazı Ahşap Yapı Malzemesi Üzerine Düşünceler", s. 3031.

17 BOA, D.00211.001.00.

18 Çûb-ı tirfil: İri taş tomruklarını taşımak üzere bunların altlarına tekerlek gibi konulan yuvarlak kesitli ağaç. Doğan Hasol, Ansiklopedik Mimarlk Sözliuğii, İstanbul 1998, s. 449.

19 Arseven, Sanat Ansiklopedisi, C I, s. 250.

20 TS.MA.d 35-0-0, 29.08.1025/11.09.1616, v. 3-216.

Belleten, Nisan 2021, Cilt: 85/Sayı: 302; 53-94 
Belgelerde sütun olarak adı geçen eleman, Arseven tarafindan yapılarda düşey olarak çoğunlukla köşelere konulan ve kesitlerine göre altılık (6 parmak) $(0,19 \mathrm{~m})$ ve sekizlik (sekiz parmak) (0,25 m) direk adı verilen dört köşe veya daire kesitli uzun ahşap olarak tanımlanmaktadır ${ }^{21}$. Tablo 3'te sütûn-1 dolma, sütûn-1 dolap eteği, sütûn-ı dolap, sütun ve bazuluk gibi çeşitleri ve ebatları verilen bu malzemenin Sultan Ahmed Külliyesi inşasında yaygın bir kullanılan alanı olduğu anlaşılmaktadır. Hımış duvar yapımında dikme, ahşap strüktürde kare kesitli diyagonal bağlantı ahşabı ve direk olarak kullanılmıştır. Ayrıca tablonun son satırında sütunun ölçüsü çap olarak verildiği için yuvarlak kesitli olduğu anlaşılmaktadır. Kullanım yeri belirtilen dikmelerden sütun-ı dolap, temel çukurunda su boşaltma işlerinde kullanılan dolabın sabitleştirilmesi için kullanılan dikmelerdir. Sütun-ı dolma ise zemini sağlamlaştırmak için belirli aralıklarla toprağın içine çakılan kazıklardı2²2.

Tablo 3: Sultan Ahmed Külliyesi inşasında kullanılan sütun çeşitleri ve ölçüleri.

\begin{tabular}{|c|c|c|c|c|c|c|}
\hline & Adet & $\begin{array}{l}\text { Tûlen } \\
\text { (Boy) }\end{array}$ & $\begin{array}{c}\text { Arzan } \\
(\text { En) }\end{array}$ & $\begin{array}{c}\text { Kalını } \\
\text { (Kalınlık) }\end{array}$ & $\begin{array}{c}\text { Birim } \\
\text { fiyat }\end{array}$ & $\begin{array}{c}\text { Toplam } \\
\text { fiyat }\end{array}$ \\
\hline Sütûn-1 dolma & 29 & 5 zirâ' & & & 25 Akçe & 725 Akçe \\
\hline Sütûn-1 dolma-i hürde & 29 & 4 zirâ $^{6}$ & & & 16 Akçe & 464 Akçe \\
\hline Sütûn-1 dolma & 100 & 4 zirâ & & & 32 Akçe & 3.200 Akçe \\
\hline Sütûn-1 dolab eteği & 210 & 6 zirâ $^{6}$ & 6 1sbi $^{6}$ & 4 1sbr ${ }^{6}$ & 25 Akçe & 5.250 Akçe \\
\hline Sütûn-1 dolab & 92 & 5 zirâ' & $5 \mathrm{ssbl}^{6}$ & 3 ssbr $^{6}$ & 60 Akçe & 5.520 Akçe \\
\hline Sütûn-1 dolab & 15 & 6 zirâ' & 5 1sbi ${ }^{6}$ & 6 ssbi $^{6}$ & 60 Akçe & 900 Akçe \\
\hline Sütûn-1 dolab & 10 & 8 zirâ' & $81 \mathrm{sbl} 1^{6}$ & 7 1sbi & 40 Akçe & 400 Akçe \\
\hline Sütûn-1 dolab-1 kebîr & 50 & 8 zirâ' & $81 \mathrm{sbl} 1^{6}$ & $81 \mathrm{sbl} 1^{6}$ & 40 Akçe & 2.000 Akçe \\
\hline
\end{tabular}

21 Arseven, Sanat Ansiklopedisi, C I, s. 468.

22 Kolay, "Osmanlı Belgelerinde Yer Alan Bazı Ahşap Yapı Malzemesi Üzerine Düşünceler”, s. 2629. 


\begin{tabular}{|l|l|l|l|l|l|l|}
\hline Bâzûluk-1 sütûn & 226 & 7 zirấ $^{6}$ & 15 ssbi $^{6}$ & 8 1sbi & & 9.718 Akçe \\
\hline Sütûn & 1 & 6 zirâ‘ & devri zirâ‘ 2 & & & 4.500 Akçe \\
\hline
\end{tabular}

Kaplama tahtaları (elvâh) da arşiv kayıtlarında geldiği yere, ağacın cinsine ve kullanıldığı yere göre sinıflandırılmaktadır ${ }^{23}$. Elvâh-1 İznikmîd (İzmit), elvâh-1 Ereğli, elvâh-ı Karapürçek gibi geldiği yere göre adlandırılan çeşitleri olduğu gibi, elvâh-1 kestane, elvâh-1 karaağaç, elvâh-1 bellût, elvâh-1 gürgen, elvâh-1 ceviz, elvâh-1 findık, elvâh-1 mütenevvia (çeşitli elvâh) gibi ağaç türüne ve elvâh-ı biçme-i âb, elvâh-ı makara gibi kullanıldığı yere veya yapım şekline göre adlandırılanları da vardır ${ }^{24}$. İzmit, Ereğli ve Karapürçek'ten temin edilen levhalar; kestane, karaağaç, pelit, gürgen, ceviz, findık ve çeşitli ağaçlardan elde edilmiştir. Karaağaç ve cevizin öncelikli kullanım alanları tablo 4'te de görüldügü üzere, caminin kapı ve pencere çerçeveleri ve kaplamalarıdır (Bk. 1-2-4-5-6-12-13). Diğer ağaç cinslerinden elde edilen levhalar da yine caminin kapı ve pencereleri başta olmak üzere hünkâr kasrı ve diğer külliye yapılarının kapı kanatları, pencere ve dolap kapakları kaplamalarında kullanılmışır'25 (Bk. 8-10). Bu levhaların bir kısmı levha olarak getirilirken; bir bölümünün de başta ceviz, fistık çamı ve şimşir olmak üzere tomruk olarak getirildiği ve işlendiği bilgisi verilmektedir ${ }^{26}$.

Tablo 4: Sultan Ahmed Külliyesi inşasında kullanılan elvâh çeşitleri ve ölçüleri.

\begin{tabular}{|l|l|l|l|l|l|}
\hline \multicolumn{1}{|c|}{ Kereste cinsi } & Adet & Tûlen (Boy) & Arzan (En) & Birim fiyat & \multicolumn{1}{c|}{$\begin{array}{c}\text { Toplam } \\
\text { fiyat }\end{array}$} \\
\hline $\begin{array}{l}\text { Elvâh-1 } \\
\text { karaağaç }\end{array}$ & 12 & 6 zirâ‘ & 18 sbb' & 120 Akçe & 1.440 Akçe \\
\hline $\begin{array}{l}\text { Elvâh-1 } \\
\text { karaağaç }\end{array}$ & 28 & 7 zirâ‘ & 181 sbi $^{6}$ & 120 Akçe & 3.360 Akçe \\
\hline $\begin{array}{l}\text { Elvâh-1 ceviz-i } \\
\text { kebîr }\end{array}$ & 5 & 7 & 20 & 600 Akçe & 3.000 Akçe \\
\hline
\end{tabular}

23 Kolay, "Osmanlı Belgelerinde Yer Alan Bazı Ahşap Yapı Malzemesi Üzerine Düşünceler”, s. 3031.

24 TS.MA.d 35-0-0, 29.08.1025/11.09.1616, v. 3-216.

25 TS.MA.d 35-0-0, 29.08.1025/11.09.1616, v. 244a, 244b.

26 TS.MA.d 35-0-0, 29.08.1025/11.09.1616, v. 8a,15b, 22b, 127a, 127b, 175b.

Belleten, Nisan 2021, Cilt: 85/Say1: 302; 53-94 
Şah-ı merdan, sırık-ı sürn, kolluk gibi ebadı ve işlevi farklı ahşap malzemeler de Sultan Ahmed Camii inşasında kullanılmıştır ${ }^{27}$. Ayrıca elvâh-ı sefine başlı̆̆ı altında gemilerden gelen ahşap levhaların da kullanıldığı bildirilmektedir. Elvâh-ı hürde ve ahşâb-1 köhne de benzer bir şekilde kullanılmış yahut değersiz keresteden yeniden dönüştürülen ahşap malzemeyi ifade eder ve inşa sürecinde bu malzemeler de kullanılmıştır28.

Verke (virke, vergeh) kiriş olarak kullanılır. "Virke", "verke" veya "vergeh" olarak belgelerde geçen kiriş ile ilgili fazla açıklayıcı bilgi bulunmamaktadır. ${ }^{29}$ Verke-i siyâh, verke-i kâfir (Avrupa'dan getirilen ahşaptan biçilmiş kiriş olmalıdır), verke-i gâver, verke-i siyah-1 gürgen, verke-i çam ve verke-i taban, verke-i taban-1 kebir gibi çeşitleri inşa rûznamçesinde yer alan verkenin sadece taban-1 verke cinsinin ölçüleri verilmektedir. 55 adet için 8.250 Akçe ücretle yapılan bir alımda ölçülerin tûlen 15 zirâ', arzan 8 ve 6 ssbı' olduğu görülmektedir. Başka bir alımda 26 adet için 3.900 Akçe ödenen malzemenin ebadı tûlen 15 zirâ', arzan 7 ve 6 ssbı', 50 adet içinse 7.500 Akçe ücrete tûlen 11 zirâ', arzan 6 ssbi', kalını 5 1sbı' olduğu görülür ${ }^{30}$. Süleymaniye Külliyesi inşaatıyla ilgili belgelerde ise "verke" alımı pek çok yerde geçmekte fakat sadece iki tanesinde bu malzemenin uzunluğu 10 zirâ‘ (7,58 m) olarak belirtilmektedir. 1640 tarihli Narh Defteri'nde ise dört tür "vergeh" olduğu belirtilmekte fakat ölçüleri hakkında bilgi yer almamaktadır ${ }^{31}$.

"Taban" veya "taban-1 virke", "taban-1 vergeh" (taban kirişi) olarak adı geçen ahşap malzemenin kullanımı günümüzdeki kullanımı ile aynıdır, daha açık bir ifadeyle dikmeleri birbirine bağlayan kiriştir ${ }^{32}$. İnşa evrakında "taban-ı Rumeli-i kebir", "taban-1 Rumeli-i meyâne", "taban-1 Karasu", "taban-ı Üsküdar" gibi geldiği yere göre veya ahşabın türüne veya boyutuna göre "taban-ı verdinar" (köknar tabanı kirişi), "taban-1 verke", "taban-1 hürde", "taban-ı tesliye", "taban-ı baskı", "taban-1 âkeşte" şeklinde adlandırıldığı görülmektedir. Dikme ve kirişlerin üzerine oturduğu bu elemanın ebadı ile ilgili inşa evrakında pek çok bilgi mevcuttur. Tablo 5 ’te bu konuda daha detaylı bilgiler yer almaktadır.

27 BOA, D.00211.001.00.

28 TS.MA.d 35-0-0, 29.08.1025/11.09.1616, v. 189a, 190a, 194a, 232a.

29 Kolay, "Osmanlı Belgelerinde Yer Alan Bazı Ahşap Yapı Malzemesi Üzerine Düşünceler”, s. 3031.

30 TS.MA.d 35-0-0, 29.08.1025/11.09.1616, v. 23b, 34a.

31 Kolay, “Osmanlı Belgelerinde Yer Alan Bazı Ahşap Yapı Malzemesi Üzerine Düşünceler”, s. 3031.

32 Kolay, "XVI. Yüzyılda Kullanılan Bazı İnşaat Malzemeleri ve Kullanım Yerleri”, s. 73. 
Tablo 5: Sultan Ahmed Külliyesi inşasında kullanılan taban çeşitleri ve ölçüleri.

\begin{tabular}{|c|c|c|c|c|c|c|c|}
\hline & Cins & Adet & $\begin{array}{l}\text { Tûlen } \\
\text { (Boy) }\end{array}$ & $\begin{array}{c}\text { Arzan } \\
(\text { En })\end{array}$ & $\begin{array}{c}\text { Kalını } \\
\text { (Kalınlık) }\end{array}$ & $\begin{array}{c}\text { Birim } \\
\text { Fiyat }\end{array}$ & $\begin{array}{c}\text { Toplam } \\
\text { Fiyat }\end{array}$ \\
\hline \multirow[t]{3}{*}{$\begin{array}{l}\text { An-yed-i } \\
\text { Menteş } \\
\text { Yahûdî }\end{array}$} & Taban-ı kebîr & 215 & ? zirâ' & 4 ssbi $^{6}$ & 4 ssbi $^{6}$ & $\begin{array}{c}480 \\
\text { Akçe }\end{array}$ & $\begin{array}{c}103.200 \\
\text { Akçe }\end{array}$ \\
\hline & Taban-1 kebîr & 15 & 15 zirâ‘ & 7 1sbi' & 8 ssbi & $\begin{array}{r}360 \\
\text { Akçe }\end{array}$ & $\begin{array}{l}5.400 \\
\text { Akçe }\end{array}$ \\
\hline & Taban-1 kebîr & 97 & 15 zirấ $^{6}$ & 7 1sbi ${ }^{6}$ & $5 \mathrm{sbl}^{6}$ & $\begin{array}{r}150 \\
\text { Akçe }\end{array}$ & $\begin{array}{l}14.500 \\
\text { Akçe }\end{array}$ \\
\hline \multirow[t]{13}{*}{$\begin{array}{l}\text { Bahâ-i ahşâb-1 } \\
\text { mütenevvi'a } \\
\text { an-yed-i Kara } \\
\text { Yorgi }\end{array}$} & Taban-1 Rumeli & 238 & 10 zirâ $^{6}$ & 6 ssbi $^{6}$ & 3 1sbi' & $\begin{array}{c}70 \\
\text { Akçe }\end{array}$ & $\begin{array}{l}16.660 \\
\text { Akçe }\end{array}$ \\
\hline & Taban-ı Rumeli & 140 & 12 zirâ $^{6}$ & 6 ssbi $^{6}$ & 4 ssbi' & $\begin{array}{c}90 \\
\text { Akçe }\end{array}$ & $\begin{array}{l}12.600 \\
\text { Akçe }\end{array}$ \\
\hline & Taban-1 Rumeli & 405 & 11 zirấ & 6 1sbi $^{6}$ & 4 1sbi' & $\begin{array}{c}40 \\
\text { Akçe }\end{array}$ & $\begin{array}{l}16.200 \\
\text { Akçe }\end{array}$ \\
\hline & Taban-ı Rumeli & 438 & 9 zirâ' & $51 \mathrm{sbl} 1^{6}$ & 3 ssbi & $\begin{array}{c}38 \\
\text { Akçe } \\
\end{array}$ & $\begin{array}{c}16.644 \\
\text { Akçe }\end{array}$ \\
\hline & Taban-ı Rumeli & 639 & 7 zirâ' & 6 1sbi & 3 ssbi & $\begin{array}{c}40 \\
\text { Akçe }\end{array}$ & $\begin{array}{c}25.560 \\
\text { Akçe }\end{array}$ \\
\hline & $\begin{array}{c}\text { Taban-1 Rumeli-i } \\
\text { kebîr }\end{array}$ & 960 & 12 & 6 1sbi' & 4 ssbi' & $\begin{array}{c}40 \\
\text { Akçe }\end{array}$ & $\begin{array}{c}38.400 \\
\text { Akçe }\end{array}$ \\
\hline & $\begin{array}{c}\text { Taban-ı Rumeli-i } \\
\text { meyâne }\end{array}$ & 443 & 8 zirâ' & $4,5 \mathrm{ssbi}^{6}$ & 2,5 ssbi ${ }^{6}$ & $\begin{array}{c}20 \\
\text { Akçe }\end{array}$ & $\begin{array}{l}8.860 \\
\text { Akçe }\end{array}$ \\
\hline & $\begin{array}{c}\text { Taban-1 Rumeli-i } \\
\text { meyâne }\end{array}$ & 336 & 8,5 zirâ‘ & 3 ssbi & $4 \mathrm{Isbl}^{6}$ & $\begin{array}{c}33 \\
\text { Akçe }\end{array}$ & $\begin{array}{l}11.088 \\
\text { Akçe }\end{array}$ \\
\hline & $\begin{array}{c}\text { Taban-1 Rumeli-i } \\
\text { vasat }\end{array}$ & 520 & 5 zirâ' & 4 1sbi & 3,5 ssbi & $\begin{array}{c}25 \\
\text { Akçe }\end{array}$ & $\begin{array}{l}13.000 \\
\text { Akçe }\end{array}$ \\
\hline & $\begin{array}{c}\text { Taban-1 pehlü-yi } \\
\text { kebîr }\end{array}$ & & 11 zirấ & 7 1sbi & 8 1sbi' & & $\begin{array}{l}9.600 \\
\text { Akçe }\end{array}$ \\
\hline & Verdinar & 2 & 18 zirâ $^{6}$ & 8 1sbi ${ }^{6}$ & 8 ssbi $^{6}$ & & 240 Akçe \\
\hline & $\begin{array}{c}\text { Taban-1 verdinar } \\
\text { der-meyâne } 10 \\
\text { adet }\end{array}$ & 8 & 16 zirâ' & 8 1sbi' & $8 \mathrm{Isbl}^{6}$ & & \\
\hline & Verdinâr-1 kebîr & 82 & 17 zirấ & 8 1sb1 & 7 ssbi & $\begin{array}{r}175 \\
\text { Akçe }\end{array}$ & $\begin{array}{l}14.350 \\
\text { Akçe }\end{array}$ \\
\hline
\end{tabular}




\begin{tabular}{|c|c|c|c|c|c|c|c|}
\hline & Taban-ı üstüvâr & 53 & 10,5 zirâ' & $6 \mathrm{ssbi}^{6}$ & $51 \mathrm{sbl} 1^{6}$ & $\begin{array}{c}120 \\
\text { Akçe }\end{array}$ & $\begin{array}{l}6.360 \\
\text { Akçe }\end{array}$ \\
\hline & Taban-1 Karasu & 33 & 14,5 zira' & $7 \mathrm{sbl}^{6}$ & 6 ssbi $^{6}$ & $\begin{array}{c}360 \\
\text { Akçe }\end{array}$ & $\begin{array}{c}11.880 \\
\text { Akçe }\end{array}$ \\
\hline & Taban-ı Üsküdar & 30 & 6 zira & 6 ssbi $^{6}$ & 2 ssbi & $\begin{array}{c}60 \\
\text { Akçe }\end{array}$ & $\begin{array}{l}1.800 \\
\text { Akçe }\end{array}$ \\
\hline & Taban-ı baskı & 10 & & & & $\begin{array}{c}30 \\
\text { Akçe }\end{array}$ & 300 Akçe \\
\hline & Taban-ı âkeşte & 10 & & & & $\begin{array}{c}30 \\
\text { Akçe } \\
\end{array}$ & 300 Akçe \\
\hline & Taban-1 kemer & 3 & 12 zirâ $^{6}$ & 7 ssbi $^{6}$ & $6 \mathrm{sbl}^{6}$ & $\begin{array}{c}120 \\
\text { Akçe }\end{array}$ & 360 Akçe \\
\hline
\end{tabular}

Çûb, çubuk, kereste, taban, verke, elvâh ve sütun gibi çeşitleriyle Sultan Ahmed Külliyesi inşasında kullanılan ahşap malzemeleri ve özellikleri inşa evrakında yer aldığı şekilde buraya alınmıştır. Bunların haricinde de kullanıldığı belirtilen fakat hakkında çok bilgi olmayan ahşap yapı malzemeleri de mevcuttur. Bunlardan biri Sultan Ahmed Külliyesi inşasında kullanılan ahşap malzemelerin cins, adet ve fiyatlarının verildiği tablo 6'da "kavâzık-ı kebîr" olarak geçen malzemedir. Büyük kazıklar şeklinde adlandırabileceğimiz bu eleman ise, 4,00 m uzunluğunda $0,08 \mathrm{x}$ 0,16 m kesitinde kalas olarak tanımlanan çapadır. 1640 tarihli Narh Defteri’nde "sütun-ı çapa"nın büyük olanının ebatları 12 zira $(9,10$ m) x 10 parmak x 10 parmak olarak verilmektedir ${ }^{33}$. İnşa evrakında (büyük) sıfatı ile birlikte kullanılan çapanın, yapının çeşitli yerlerinde kullanılan, kesit ve uzunluğa bağlı olarak büyük ahşapları tanımladığını ortaya koymaktadır ${ }^{34}$.

Yine inşa rûznamçesinde "mertek-i Samanlu" "mertek-i çam" ve "mismâr-1 mertek" olarak geçen çatı merteğinin o dönemde çoğunlukla İzmit'in Samanlı Dağları'ndan getirildiği, çamdan imal edildiği ve özellikle örtü sisteminde kullanıldığı anlaşılmaktadır ${ }^{35}$. Ayrıca tablo 6'da yer alan teneke-i tavan ve sanduk

33 Mübahat S. Kütükoğlu, Osmanllarda Narh Müessesesi ve 1640 Tarihli Narh Defteri, İstanbul 1983, S. 294.

34 Kolay, "Osmanlı Belgelerinde Yer Alan Bazı Ahşap Yapı Malzemesi Üzerine Düşünceler”, s. 29.

35 Kısa, kare kesitli kereste, baba, payanda, makas, çatı makası, altgergi, üstbaşlık. Kolay, "Osmanlı Belgelerinde Yer Alan Bazı Ahşap Yapı Malzemesi Üzerine Düşünceler”, s. 37-38. Mertek Taban tahtalarının çivilendiği ağaç. 2. Çift kanatlı pencere çerçevelerinin ortasına çakılan çıta. 3. Bir yere konulan destek. Kazık (www.sozluk.gov.tr) 
da ince ahşap kaplama levhaları olarak, hem saçak altı kaplama tahtası olarak hem de saklama amaçlı yapılan sandıklarda kullanılmıştır ${ }^{36}$.

Tablo 6: Sultan Ahmed Külliyesi inşasında kullanılan ahşap malzemelerin cinsi, fiyatı ve ücreti.

\begin{tabular}{|c|c|c|c|}
\hline \multicolumn{4}{|c|}{$\begin{array}{c}\text { Sultan Ahmed Camii İnşası sürecinde Kullanılan Ahşap malzeme çeşitleri ve } \\
\text { kullanım özellikleri }\end{array}$} \\
\hline Malzeme & Kereste Çeşidi & Adet & Toplam fiyat \\
\hline Pedavra & Pedavra-i dırâz & 567.690 & 204.159 Akçe \\
\hline \multirow{11}{*}{ Çûb/çubuk } & Çûb-1 binar & 4.786 & 57.502 Akçe \\
\hline & Çûb-1 tirfîl & 388 & 9.700 Akçe \\
\hline & Çûb-1 makaslık, & 38.545 & 448.413 Akçe \\
\hline & Çûb-1 abanoz & 1188 & 71.280 Akçe \\
\hline & Çûb-1 şimşir & 190 & 5.000 Akçe \\
\hline & Çûb-1 cevherdârî & $2.534,5$ & 152.070 Akçe \\
\hline & Çubuk-1 harcî & 700 & 3.500 Akçe \\
\hline & Ģûb-1 çubuk-1 körpe & 5.358 & 39.569 Akçe \\
\hline & Tomruk-1 çûb-1 siyâh & 6 & 1.320 Akçe \\
\hline & Bazuluk & 1357 & 53.359 Akçe \\
\hline & Şâh-1 merdan & 11 & 720 Akçe \\
\hline \multirow{6}{*}{ Sütun } & Sütûn-1 meyâne & 39 & 1.176 Akçe \\
\hline & $\begin{array}{l}\text { Sütûn-1 dolab-1 kebir- } \\
\text { vasat }\end{array}$ & 4.129 & 223.220 Akçe \\
\hline & Sütûn-1 dolma & 13.337 & 329.492 Akçe \\
\hline & Sütûn-1 Üsküdar & 3 & 1.800 Akçe \\
\hline & Sütûn-1 karaağaç & 56 & 14.560 Akçe \\
\hline & Sütûn-1 ayak dolabı & 1982 & 99.550 Akçe \\
\hline
\end{tabular}

36 Serpil Çelik, Süleymaniye Külliyesi, Malzeme, Teknik ve Sürȩ, Ankara 2009, s. 263.

Belleten, Nisan 2021, Cilt: 85/Sayı: 302; 53-94 
Sultan Ahmed Külliyesi'nde Ahşap Malzeme Kullanımı

\begin{tabular}{|c|c|c|c|}
\hline \multirow{15}{*}{ Elvâh } & Elvâh-1 İznikmîd & 3.194 & 21.069 Akçe \\
\hline & Elvâh-1 Ereğli & 200 & 1900 Akçe \\
\hline & Elvâh-1 Karapürçek & 5.833 & 44.887 Akçe \\
\hline & Elvâh-1 kestane & 1.398 & 7.958 Akçe \\
\hline & Elvâh-1 karaağaç & 1.277 & 83.630 Akçe \\
\hline & Elvâh-1 bellût & 31.758 & 2 yük 5.612 Akçe \\
\hline & Elvâh-1 gürgen & 20.650 & 140.160 Akçe \\
\hline & Elvâh-1 ceviz & 2.167 & 139.015 Akçe \\
\hline & Elvâh-1 findık & 392 & 22.174 Akçe \\
\hline & Elvâh-1 mütenevvia & 14.382 & 148.615 Akçe \\
\hline & Elvâh-1 biçme-i âb & 9.625 & 67.148 Akçe \\
\hline & Elvâh-1 ağa & 3.507 & 35.804 Akçe \\
\hline & Elvâh-1 makara & & 962 Akçe \\
\hline & Elvâh-1 sefîne & 370 & 4.370 Akçe \\
\hline & Elvâh-1 çûb-1 binar & 7 & 840 Akçe \\
\hline \multirow{2}{*}{ Verke } & Verke-i taban-ı kebîr & 103 & 14.970 Akçe \\
\hline & $\begin{array}{l}\text { Verke-i siyah ve mertek-i } \\
\text { samanlık }\end{array}$ & 4.054 & 40.592 Akçe \\
\hline \multirow{10}{*}{ Taban } & Taban-1 Rumeli-i kebir & 69.019 & 34 yük 4.640 Akçe \\
\hline & $\begin{array}{l}\text { Taban-1 Rumeli-i } \\
\text { meyâne ve çûb-1 meyane } \\
\text { ve hurde }\end{array}$ & 20.399 & 531.360 Akçe \\
\hline & $\begin{array}{l}\text { Taban-1 Karasu ve } \\
\text { taban-1 kebir }\end{array}$ & 4.099 & 14 yük 21.655 Akçe \\
\hline & Taban-1 Üsküdar & 731 & 79.430 Akçe \\
\hline & $\begin{array}{l}\text { Taban-1 verdinar, sütûn-1 } \\
\text { verdinar ve sütûn-1 } \\
\text { Bartın }\end{array}$ & 4.285 & 878.229 Akçe \\
\hline & Taban-1 verke & 1.110 & 28.870 Akçe \\
\hline & Taban-1 hurde & 14 & 360 Akçe \\
\hline & Taban-1 baskı & 10 & 300 Akçe \\
\hline & Taban-1 tesliye? & 2.534 & 104.683 Akçe \\
\hline & Taban-1 âkeşte & 96 & 13.200 Akçe \\
\hline
\end{tabular}




\begin{tabular}{|c|c|c|c|}
\hline \multirow{2}{*}{ Haşeb } & Tekne-i haşeb & & 1.102 Akçe \\
\hline & $\begin{array}{l}\text { Teneke-i tavan ve } \\
\text { sandûk }\end{array}$ & 28.574 & 171.377 Akçe \\
\hline \multirow{2}{*}{ Kavazık } & & & \\
\hline & Kavazık-1 kebir ve vasat & 2.511 & 53.972 Akçe \\
\hline \multirow{2}{*}{ Mertek } & & & \\
\hline & Mertek-i çam & 20 & 500 Akçe \\
\hline \multirow[t]{2}{*}{ Sirık } & & & \\
\hline & Sırık-1 sürn & & 1.080 Akçe \\
\hline \multirow[t]{2}{*}{ Kolluk } & & & \\
\hline & Kolluk & 3.319 & 33.190 Akçe \\
\hline Toplam & \multicolumn{3}{|l|}{94 yük 42.979 Akçe } \\
\hline
\end{tabular}

Sultan Ahmed Camii inşasında kullanılmış olan ahşap malzeme ve çeşitleri yukarıda verilen tabloda vâridât ve masârif defterinde yer alan bilgiler dâhilinde oluşturulmuştur. Bu defterde Hüseyin Kâtip bevvâbân ve dergâh-1 âlî rûznamçecisi Selim'in 01.05.1017/13.08.1608 tarihinden 30.11.1026/29.11.1617 tarihine kadar Sultan Ahmed Han'ın emriyle Darüssaade Ağası Mustafa Ağa, Bina Eminleri Kalender Efendi, Hüseyin ve İdris Ağaların nezaretinde Ser-mimaran-1 Hassa Mehmed Ağa'nın evler, dükkanlar, alt kat ve üst kat odalar, mektep, sebilhaneler ve kasr-1 hümâyûn ile birlikte inşa ettiği Sultan Ahmed Camii'nin gelir ve giderleri yer almaktadır. Bu defterde çeşitli keresteler ve es'ar-ı muhtelife bölümünde tablo 6'da görülen bütün ahşap yapı elemanları ödenen ücretlerle birlikte yer almaktadır.

Sultan Ahmed Camii ve odalar, dükkanlar, hünkâr kasrı, sebilhaneler ve mektepten oluşan külliyenin bir bölümünün gelir ve giderlerinin kaydedildiği vâridât ve masârif defterinde büyük miktarlarda ahşap malzeme alımı görülmektedir. Bu malzemelerden en çok alım ve kullanım yapılanlarının hatıl olarak temel ve duvar yapımında ve yapı iskelesinde kullanıldığı rûznamçe defterinden izlenebilmektedir. Bunun dışında örtü sistemi, kapı kanatları, pencere ve dolap kapaklarında, mobilyalar, inşa araç ve gereçleri için de ahşap malzemelerin temin edildiği ve kullanıldığı görülmektedir.

\section{Sultan Ahmed Külliyesi'nde Ahşap İşçileri}

Süleymaniye Camii inşasında kerestenin tedarik ve sevkinin organizasyonu çözümlenmiştir. Buna göre İstanbul'dan ellerinde mahallerin kadılarına hitaben 
yazılmış fermanlar ve bina emininin lüzumlu kerestenin cins, ölçü ve miktarını belirten defterleri bulunan görevliler geniş yetkilerle kereste çıkarılan bölgelere gönderilmekte ve mahallin kadısının yardımıyla satın alınan malzemeler gemilere yüklenip İstanbul'a getirilmektedir ${ }^{37}$. Aynı çerçevede gerçekleşen organizasyonda, inşa belgelerinde ahşap işlerinden sorumlu adı en çok geçen görevliler errekeşân ve neccârândır. Süreçte çok aktif rol oynayan bu iki meslek grubu, ahşap malzemelerin seçilip, bıçkı ile kesilmesinden, işlenip inşaata dâhil edilmesine kadar pek çok aşamayı gerçekleştirmiştir. Erre-keşân, bıçkı kullanarak ağaç deviren, tomruk ve tahtaları kesen işçiler grubudur.

Tablo 7: TS.MA.d 35-0-0 nolu deftere göre Sultan Ahmed Külliyesi inşasında çalışan erre-keşân işçileri ve yapılan ödemeler.

\begin{tabular}{|c|c|c|c|c|c|c|}
\hline Varak & Tarih & Meslek & Malzeme & $\begin{array}{l}\text { Görev } \\
\text { Süresi }\end{array}$ & $\begin{array}{c}\text { Kişi } \\
\text { Say1s1 }\end{array}$ & Kiymet \\
\hline v. $7 \mathrm{a}$ & $\begin{array}{l}30.07 .1018 / \\
29.10 .1609\end{array}$ & Erre-keşân & & 26 günlük & 2 & 600 Akçe \\
\hline v.8a & $\begin{array}{l}\text { 10.08.1018/ } \\
08.11 .1609\end{array}$ & $\begin{array}{l}\text { Erre-keşân } \\
\text { İ́skender, } \\
\text { Hüsrev, } \\
\text { Keyvan, } \\
\text { Müslim }\end{array}$ & $\begin{array}{l}\text { Der-vakt-i } \\
\text { reften be-cânib-i } \\
\text { Trabzon berây-1 } \\
\text { kal'-kerden-i } \\
\text { elvâh-1 ceviz ve } \\
\text { tomruk-1 şimşîr }\end{array}$ & $\begin{array}{l}\text { Yaklaşık } \\
6 \text { aylık }\end{array}$ & 20 & $\begin{array}{l}11.600 \\
\text { Akçe }\end{array}$ \\
\hline v. $10 \mathrm{a}$ & $\begin{array}{l}03.09 .1018 / \\
30.11 .1609\end{array}$ & Erre-keşân & & 13 günlük & 4 & 480 Akçe \\
\hline v. $11 \mathrm{~b}$ & $\begin{array}{l}10.10 .1018 / \\
06.01 .1610\end{array}$ & Erre-keşân & & 1 aylık & 4 & 1.680 Akçe \\
\hline v. $12 b$ & $\begin{array}{l}29.10 .1018 / \\
25.01 .1610\end{array}$ & Erre-keşân & & & 2 & 480 Akçe \\
\hline v.13a & $\begin{array}{l}29.11 .1018 / \\
23.02 .1610\end{array}$ & $\begin{array}{l}\text { Be-cihet-i } \\
\text { nafaka-i } \\
\text { hammâlân ve } \\
\text { erre-keşân }\end{array}$ & & 1 aylık & & $\begin{array}{l}67.614 \\
\text { Akçe }\end{array}$ \\
\hline
\end{tabular}

37 Ömer Lütfi Barkan, Süleymaniye Cami ve İmareti İnşaatı, C I, Ankara 1972, s. 387-393. 


\begin{tabular}{|c|c|c|c|c|c|}
\hline v. $14 b$ & $\begin{array}{l}29.12 .1018 / \\
25.03 .1610\end{array}$ & $\begin{array}{l}\text { Be-cihet-i } \\
\text { nafaka-i } \\
\text { hammâlân ve } \\
\text { erre-keşân }\end{array}$ & 1 aylik & & 3.334 Akçe \\
\hline v.16a & $\begin{array}{l}\text { 29.01.1019/ } \\
\text { 23.04.1610 }\end{array}$ & $\begin{array}{l}\text { Be-cihet-i } \\
\text { nafaka-i } \\
\text { hammâlân ve } \\
\text { erre-keşân } \\
\text { an-forsa-i mîrî }\end{array}$ & 1 aylik & 1.284 & 5.136 Akçe \\
\hline v.18a & $\begin{array}{l}02.1019 / \\
05.1610\end{array}$ & $\begin{array}{l}\text { Be-cihet-i } \\
\text { nafaka-i } \\
\text { hammâlân ve } \\
\text { erre-keşân } \\
\text { an-forsa-i mîrî }\end{array}$ & & 1.432 & 5.728 Akçe \\
\hline v. $20 \mathrm{~b}$ & $\begin{array}{l}29.03 .1019 / \\
21.06 .1610\end{array}$ & $\begin{array}{l}\text { Be-cihet-i } \\
\text { hammâlân ve } \\
\text { erre-keşân } \\
\text { an-forsa-i mîrî }\end{array}$ & & 1.590 & 6.360 Akçe \\
\hline v. $22 \mathrm{~b}$ & $\begin{array}{l}\text { 25.04.1019/ } \\
21.07 .1610\end{array}$ & $\begin{array}{l}\text { Be-cihet-i } \\
\text { nafaka-i } \\
\text { erre-keşân ve } \\
\text { hammâlânve } \\
\text { üsârâ-yı mehter }\end{array}$ & & 1.658 & 6.632 Akçe \\
\hline v. $28 \mathrm{a}$ & $\begin{array}{l}12.05 .1019 / \\
02.08 .1610\end{array}$ & $\begin{array}{l}\text { Be-cihet-i } \\
\text { nafaka-i forsa-i } \\
\text { mîrî ma'a } \\
\text { vardiyânâñ ve } \\
\text { hammâlân ve } \\
\text { erre-keşân } \\
\end{array}$ & & 306 & 6.060 Akçe \\
\hline v. $46 \mathrm{a}$ & $\begin{array}{l}11.11 .1019 / \\
25.01 .1611\end{array}$ & $\begin{array}{l}\text { Be-cihet-i } \\
\text { nafaka-i } \\
\text { vardiyân ve } \\
\text { hammâlân-1 kec } \\
\text { ve erre-keşân } \\
\text { an-forsa-i mîrî }\end{array}$ & 1 aylik & & 8.130 Akçe \\
\hline v. $114 \mathrm{a}$ & $\begin{array}{l}25.05 .1021 / \\
24.07 .1610\end{array}$ & Erre-keşân & 1 aylık & & 414 Akçe \\
\hline v. $206 \mathrm{a}$ & $\begin{array}{l}28.06 .1024 / \\
25.07 .1615\end{array}$ & Erre-keşân & & & 1.200 Akçe \\
\hline v. $249 \mathrm{a}$ & & Erre-keşân & & & 720 Akçe \\
\hline
\end{tabular}

Belleten, Nisan 2021, Cilt: 85/Sayı: 302; 53-94 
Tablo 7'de yer alan erre-keşân etkinliğinde, sayıları 2-20 arasında değişen görevlinin ağaç devrilmesi, kesimi ve taşınma sürecinde çalıştı̆̆ görülmektedir. Ayrıca aynı defterde yer alan başka bir bilgi şu şekildedir. Mimar Ağa tezkiresine göre batıdaki sebilhanenin tavan kaplaması için erre-keşân kethüdası eliyle alınanlar: teneke-i sovuk (200 adet, fî 8, kıymet 1.600), teneke-i tavan (200 adet, fî 5, kıymet 1.000), be-cihet-i hammâliyye-i mezbûr (14 hıml, fî 3, kıymet 42) yekûn $2.642^{38}$. Bu bilgiye göre erre-keşân çalışanları, ahşap malzemenin yerinden getirilip işlenmesini sağladıkları gibi, yapılan malzemelerin monte edilmesinde de montaj malzemesi alımı dâhil rol oynamışlardır. Bu durum onların hamallar ve forsa esirleri gibi niteliksiz işçilere birlikte çalışmalarını gerektirmektedir. Arşiv evrakında erre-keşâna kendi görevi nedeniyle 31.520 Akçe ödeme yapıldığı, lağımcı ve hamallarla birlikte yaptıkları görevler için de toplam 68.978 Akçe ödeme yapıldığı bildirilmektedir ${ }^{39}$. Bu durum erre-keşân ve lağımcı, hamal gibi meslek gruplarının ortak çalı̧̧malarının bir sonucu olmalıdır.

Sultan Ahmed Külliyesi inşasını kayıt altına alan evrakın muhtelif yerlerinde erre-keşân ustaları ile ilgili sınırlı da olsa isim ve görev bilgisi verilmektedir. Bu bilgilere detaylarıyla yer verip, yapı özelinde işçiler ve görevleriyle ilgili detayların paylaşılması yerinde olacaktır.

Erre-keş, Farsşa bir kelime olup, biçici anlamında kullanılmıştır ${ }^{40}$. Erre-keşân ise erre-keşin çoğuludur ve bıçkı kullanarak tomruk ve tahtaları kesen işçiler grubu olarak öncelikli görevleri ahşap malzemelerin inşa sorumlusuyla birlikte istenilen yerden getirilmesidir. Erre-keşânın ağaç temininde çıktıkları yolculuklar gidilen yere ve vasıtaya göre süre açısından farklılıklar göstermektedir. İnşa evrakında bu konuda ilk bilgi, 167 gün için 10.08.1018/08.11.1609'dan 30.01.1019/24.04.1610 sonuna kadar şimşir tomruğu ve ceviz levhalar getiren Üstad Hasan'a 5.010 Akçe ödeme yapılması şeklindedir. Yine aynı görevde Üstad Hasan'a eşlik eden Mehmed Bevvâb’a günlüğü 20 Akçe'den 3.540 Akçe ödenmiştir. Devamında aynı sürede Kara Halîfe ve Bevvâb Mehmed'le birlikte Trabzon tarafindan ceviz levhalar ve şimşir tomruğu kesmek için erre-keşân İskender, Hüsrev, Keyvan, Müslim’e 11.600 Akçe ödeme yapıldığı bildirilmektedir ${ }^{41}$. Üstad Hasan, Mehmed Bevvâb, Kara Halife gibi inşa sorumluları ile birlikte işçiler olarak İskender, Hüsrev,

38 TS.MA.d 35-0-0, 29.08.1025/11.09.1616, v. 197b.

39 BOA.D. 00040.001.

40 Cafer Efendi, Risâle-i Mimâriyye, s. 110.

41 TS.MA.d 35-0-0, 29.08.1025/11.09.1616, v. 8a.

Belleten, Nisan 2021, Cilt: 85/Say1: 302; 53-94 
Keyvan ve Müslim geçmektedir. Trabzon'dan deniz yoluyla ceviz levhalar ve şimşir tomruk getirmişlerdir.

İnşa evrakında bir sonraki bölümde Mehmed Çelebi eliyle alınan ceviz levhalar için 420 Akçe ödendiği bildirilmektedir ${ }^{42}$. 19.12.1018/15.03.1610 tarihi itibariyle Menteş Yahudi tarafindan forsa esirleriyle Marmara adasından getirilen çeşitli aletler ve sütun taşıma ücreti yanında ceviz levhaların da alındığı ve toplam 33.520 Akçe masraf yapıldığı kaydedilmektedir ${ }^{43}$. Marmara Adası'ndan forsa esirleriyle getirilen ceviz levhalar, ilk alıma göre epeyce azdır ve satın alınmış olma ihtimali mevcuttur.

İnşa sürecinde bir sonraki alım bilgisi, Karaburun'dan Üstad Hasan'ın taşıyıcıllğıyla 79 adet ceviz levha için tanesi 20 Akçe'den 1.580 Akçe ödeme yapıldığı şeklindedir. Arslan Reis gemisiyle Üstad Hasan'ın getirdiği 324 adet fistık çamı tomrukları içinse adeti 5 Akçe'den 1.620 Akçe ödeme yapıldığı görülmektedir. Aynı gemide gelen ceviz levhalar ve Şimşir levhalar için 1.580 Akçe ödeme yapıldığı belirtilir ${ }^{44}$. Deniz yoluyla Karaburun/İzmir tarafindan getirilen fistık çamı tomrukları, ceviz ve şimşir levhalar için Üstad Hasan'ın çalıştı̆̆ ve Arslan Reis'in gemisinin işçi ve malzeme nakli için kullanıldığı görülmektedir.

Mehmed Bâşe eliyle 717 adet 10 Akçe'den ceviz levhalar için 7.170 Akçe ödeme yapıldığı yine ruznamçede yer almaktadır ${ }^{45}$. Hemen akabinde İskender Bâşe gemisiyle Mahmud Bevvâb eliyle Hasan'ın listesiyle 35 adet ceviz levhalara tanesi 40 Akçe'den 1400 Akçe ödendiği görülür ${ }^{46}$. Mehmed Bevvâb'n mübaşeretiyle ser-mimaran-1 hassa Hasan'ın listesiyle 170 adet ceviz levhalar için tanesi 40 Akçe'den 6800 Akçe ödeme yapıldığı kaydedilmişti ${ }^{47}$. Böylece inşa sorumluları olarak Mehmed Bevvâb, Mahmud Bevvâb, Mehmed Bâşe ve İskender Bâşe gösterilmekte ve ahşap malzemelerin tespitinin mimarbaşı listelerine göre yapıldığı belirtilmekte ancak getirildiği yer bildirilmemektedir.

01.02.1019/25.04.1610-12.04.1019/04.07.1610 tarihleri arasinda hassa mimarlarından Üstad Hasan ve Dergâh-1 Âlî bevvâblarından Mehmed eliyle, Sinop ka-

42 TS.MA.d 35-0-0, 29.08.1025/11.09.1616, v. 11 a.
43 TS.MA.d 35-0-0, 29.08.1025/11.09.1616, v. 14 a.
44 TS.MA.d 35-0-0, 29.08.1025/11.09.1616, v. 15b.
45 TS.MA.d 35-0-0, 29.08.1025/11.09.1616, v. 18b.
46 TS.MA.d 35-0-0, 29.08.1025/11.09.1616, v. 19b.
47 TS.MA.d 35-0-0, 29.08.1025/11.09.1616, v. 22a.

Belleten, Nisan 2021, Cilt: 85/Sayı: 302; 53-94 
zasından 175 adet ceviz levhaya 20 Akçe'den 3.500 Akçe ödenmiştir. Aynı şekilde Sinop'tan İstanbul'a getirilen 459 adet ceviz levhalara, 325 adet fistık çamı tomruklarına ve fistık çamı tomruklarının gemi navlun ücretine 14.470 Akçe ödenmiştir. Sinop'tan gelen levhalar ve tomruklar için 915 Akçe mahzen kirası, Giresun kazasından ceviz levhalar ve tomrukların 960 Akçe navlun bedeli ve sonraki taşımalar için 800 Akçe ödenmiştir. Akabinde ceviz levhaların sslahı için 400 Akçe ücret ödendiği, Trabzon'dan alınan ceviz levhalar ve fistık çamı tomrukları için dönüş yolunda 50 gün için Üstad Hasan'a günlüğü 30 Akçe'den, Mehmed bevvâb’a günlüğü 200 Akçe'den 3.550 Akçe ücret ödendiği evrakta bildirilmektedir ${ }^{48}$. Bu bilgilere dayanarak Üstâd Hasan ve Mehmed Bevvâb eliyle Sinop, Giresun ve Trabzon'dan ceviz levhalar ve fistık çamı tomrukları getirildiği çıkarılabilir.

İnşa evrakında karşımıza çıkan bir sonraki bilgi, Mustafa Efendi eliyle mimar ağa tezkiresine göre cami-i şerif pencereleri mühimmâtı için 43 adet ceviz levhalara 4300 Akçe ödeme yapılmasıdır ${ }^{49}$. Yine Mimar Ağa tezkiresine göre Topçu Dive eliyle gelecek 86 adet ceviz levha için 6.880 Akçe ödenmiştir ${ }^{50}$. Cami pencereleri için Mustafa Efendi ve Topçu Dive eliyle ceviz levhalar alındığı bildirilmekte, fakat nereden alındığına dair bilgi verilmemektedir. Devamında cami-i şerif pencereleri mühimmatı için Üstad Hasan'a 38 adet ceviz levhalar için 3.990 Akçe ödeme yapıldığı görülmektedir ${ }^{51}$.

Yine cami-i şerif kapıları ve pencereleri mühimmatı için Mimar Ağa marifetiyle emîn-i hatab (Odun Emini) eliyle alınan 231 adet ceviz levhalara 26.565 Akçe ücret ödendiği bildirilmektedir ${ }^{52}$. Cami-i şerif pencereleri mühimmatı için Üstad Hasan eliyle alınan 38 adet ceviz levhalar için 3.990 Akçe masraf pahası ödendiği kaydedilmiştir. Cami-i şerifin devam eden mühimmatı için Ali Bâşe eliyle büyük ceviz levhalardan 5 adet için 3000 Akçe ödeme yapıldığı görülür. (5 adet, tûlen 7 , arzan 20, kadden 5, fî 600, klymet 3.000) ${ }^{53}$.

Turhan Ağa ve Mustafa Ağa eliyle şimşir keresteleri ve ceviz levhalar için 142 adet üzerinden 19.880 Akçe ödendiği görülür. Ceviz levhalar kâtibi, Ömer eliyle

48 TS.MA.d 35-0-0, 29.08.1025/11.09.1616, v. 22b.

49 TS.MA.d 35-0-0, 29.08.1025/11.09.1616, v. 115b.

50 TS.MA.d 35-0-0, 29.08.1025/11.09.1616, v. 127a.

51 TS.MA.d 35-0-0, 29.08.1025/11.09.1616, v. 127a.

52 TS.MA.d 35-0-0, 29.08.1025/11.09.1616, v. 145b.

53 TS.MA.d 35-0-0, 29.08.1025/11.09.1616, v. 160b.

Belleten, Nisan 2021, Cilt: 85/Say1: 302; 53-94 
38 adet ceviz levha için 1900 Akçe, 5 adet tomruk için 200 Akçe, 35 adet daha tomruk için 1050 Akçe ödeme izlenmektedir ${ }^{54}$. Ramazan Reis eliyle 42 adet küçük ceviz levhalar için 1.470 Akçe, 46 adet büyük ceviz levhalar için 2.270 Akçe ödendiği geçer ${ }^{55}$.

Mimar Ağa tezkiresine göre Ahmed eliyle alınan 5 adet ceviz levhalara 2000 Akçe ödendiği de kaynaklarda geçmektedir ${ }^{56}$. Yine mimar ağa tezkiresine göre Karaca Turgut eliyle alınan 35 adet ceviz levha için 2.275 Akçe ödeme yapıldığı bildirilmektedir ${ }^{57}$.

Mimar Ağa tezkiresine göre defaatle cami-i şerif camları çerçeveleri için Ahmed Çelebi vasıtasıyla Dimitri eliyle alınan büyük karaağaç (çûb-ı siyâh-ı kebîr) levhalar pahası olarak 100 adet, 120 Akçe’den 12.000 Akçe ${ }^{58}$ ödeme yapıldığı bildirilmektedir. Cami çerçeveleri için karaağaç levhaların tercih edildiği önceki bölümde de yer almıştır. Ancak bu ağaçların seçimi ve getirilmesinde Ahmed Çelebi vasıtasıyla Dimitri'nin rol oynadığı ve bir sonraki bilgide de solak İbrahim Çelebi, Bodur Cafer ve Kasım eliyle alınan karaağaç ve bunların kullanıldığı yerler açık bir şekilde zikredilmektedir.

Buna göre, mimar ağa tezkiresine göre cam çerçeveleri için solak İbrahim Çelebi eliyle karaağaç levhalar pahası olarak 12 adet tûlen 6 zirâ', arzan 18 ssbı' ebadında ürünlere 120 Akçe'den 1.440 Akçe ödenmiştir. Bahsi geçen tezkireye göre Bodur Cafer eliyle karaağaç levhalar pahası ise tûlen 7 zirâ‘, arzan 18 1sbı‘ ebatlarında 28 adet için 120 Akçe'den 3.360 Akçe ödenmiştir. Bahsi geçen tezkireye göre Kasım eliyle de karaağaç levhalar pahası olarak 32 adet için 170 Akçe'den 3.840 Akçe ödenmiştir ${ }^{59}$.

Sultan Ahmed Külliyesi'nin özellikle pencere ve kapılarında kullanılan ceviz ve şimşir levhalar ile şimşir ve fistık çamı tomrukların temininde inşa evrakında pek çok görevlinin adı geçmektedir. Bunlar Üstad Hasan, Mehmed Bevvâb, Kara Halife, İskender, Hüsrev, Keyvan, Müslim, Mehmed Çelebi, Menteş Yahudi, Arslan Reis, Mahmud Bevvâb, Mehmed Bâşe, İskender Bâşe, Mustafa Efendi,

54 TS.MA.d 35-0-0, 29.08.1025/11.09.1616, v. 175b.

55 TS.MA.d 35-0-0, 29.08.1025/11.09.1616, v. 176b.

56 TS.MA.d 35-0-0, 29.08.1025/11.09.1616, v. 229a.

57 TS.MA.d 35-0-0, 29.08.1025/11.09.1616, v. 233 a.

58 TS.MA.d 35-0-0, 29.08.1025/11.09.1616, v. 196b.

59 TS.MA.d 35-0-0, 29.08.1025/11.09.1616, v. 233b. 
Topçu Dive, Turhan Ağa, Mustafa Ağa, Ali Bâş̧e, Ramazan Reis, Karaca Turgut, Ahmed Çelebi, Dimitri, solak İbrahim Çelebi, Bodur Cafer ve Kasım'dır.

Neccâr/Neccârân ise, ahşap malzeme ve kaplama kullanarak binaların iç ve dış aksamını ahşap malzemeler ile kaplayan; kapı, pencere, dolap, merdiven, pano, kepenk, kapak vb. yapan ve takan iş̧iler grubudur ${ }^{60}$. Sultan Ahmed Camii merkezli külliyenin inşa sürecinden günü gününe bahsedilen rûznamçede neccâran işçi grubunun işleri ile ilgili 198 kayıt mevcuttur. Saylları zaman zaman 600’ü bulan neccârân, esirân-1 mîrî, esîrân-ı forsa, esîrân-1 Ali Paşa, Esîrân-1 Sadrazam Mehmed Paşa ve vardiyeli olmak üzere birkaç sınıftan oluşuyordu. Köstendil, Midilli $^{61}$, Gelibolu, Selanik, adalar ${ }^{62}$, Filibe, Sofya, Molova ${ }^{63}$, Amasya, Köstendil, Bihlişte $^{64}$, İvranya ${ }^{65}$, Edirne ${ }^{66}$, Imroz ${ }^{67}$, gibi yerlerden ustalar getirilerek kalifiye elemanı arttırılan bu grubun içinde üstâdlar, sayıları 35’i bulan neccâr halifeleri ve şakirtleri mevcuttur ${ }^{68}$.

İnşa sürecinde neccârân sınıfının fazla sayıda ve görevde yer almasının sebebi kapı kanatları, dolap ve pencere kapakları vb. ahşap yapı elemanlarının serbest piyasadan hazır olarak alınmayarak ahşap malzemelerinin atelyelerde istenen ölçülerde üretilmesi olabilir. Rûznamçe defterindeki alımlar bu durumu destekler niteliktedir. Ayrıca mimar tezkiresiyle neccârânın inşa sahasında atıl vaziyetteki imam evi, duvarlar gibi yapıların yıkılmasında da görev aldığı ve geri dönüştürülecek malzemeyi çıkarmaları inşa rûznamçesinde geçmektedir ${ }^{69}$. Ayrıca Maltepe iskelesi ve Şühûd kapısındaki kereste ambarının tamirini de kalfalarıyla birlikte neccârânın yaptığı kaydedilmişti ${ }^{70}$.

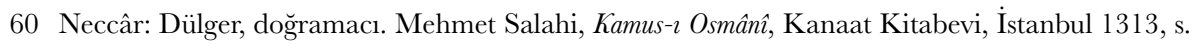
574.

61 TS.MA.d 35-0-0, 29.08.1025/11.09.1616, v. 28b, 29a.

62 TS.MA.d 35-0-0, 29.08.1025/11.09.1616, v. 56b.

63 TS.MA.d 35-0-0, 29.08.1025/11.09.1616, v. 64b.

64 TS.MA.d 35-0-0, 29.08.1025/11.09.1616, v. 79b.

65 TS.MA.d 35-0-0, 29.08.1025/11.09.1616, v. 82b.

66 TS.MA.d 35-0-0, 29.08.1025/11.09.1616, v. 108b.

67 TS.MA.d 35-0-0, 29.08.1025/11.09.1616, v. $110 \mathrm{~b}$.

68 TS.MA.d 35-0-0, 29.08.1025/11.09.1616, v. 48a.

69 TS.MA.d 35-0-0, 29.08.1025/11.09.1616, v. 169a.

70 TS.MA.d 35-0-0, 29.08.1025/11.09.1616, v. 85a.

Belleten, Nisan 2021, Cilt: 85/Say1: 302; 53-94 
29.04.1025/16.05.1616 tarihli rûznamçe kaydında cami-i şerif pencereleri kaplaması için yapılan masraflar mevcuttur. Bu belgeye göre seng-traş Mustafa Konya'ya 105 zirâ' tanesi 80 Akçe'den 8.400 Akçe ücret, padişah mahfili pencerelerinden birinin kaplamaları için 3 kantar 18 lodura, kıyye hesanıyla 139,5 malzemeye 120 Akçe'den 16.740 Akçe ücret, nühâs tavan için 6 adet, 12,5 kıyye için tanesi 40 Akçe'den 500 Akçe ücret ve tunç pencerelerin 5 adetinin tamiri için 2.000 Akçe'den 10.000 Akçe ücret olmak üzere toplam 765.010 Akçe ödendiği görünmektedir. ${ }^{71}$ Burada Padişah mahfili ve cami pencereleri için kaplama ustası olarak seng-traş Mustafa Konya adı geçmektedir. Özellikle seng-traş (taş yontucu) olarak mesleği tanımlanan Mustafa Konya'nın, ağaç yontucu olarak, özellikle padişah mahfili diye geçen hünkâr mahfilinde sedef kakma için künde (badem) oyma ve künde yuvalarını boşaltma görevini de yapmış olabileceği düşünülebilir.

Sultan Ahmed Külliyesi'nde kiralık odalar ${ }^{72}$ ve cami pencerelerinde muşamma ${ }^{93}$ kullanıldığı arşiv evrakında yer almaktadır ${ }^{74}$. 04.11.1024/ 25.11.1615 tarihli bilgide Şehrî Çilingir eliyle alınan ihtiyaç listesinde muşamba ile birlikte kullanılan malzemeler geçmektedir. $\mathrm{Bu}$ malzemeler şöyle sıralanmıştır; bend-kûşe-i muşamma' kullâblu (40 adet), halka-i muşamma' bâ-kullâb (20 adet), mandal-i muşamma' kullâblu (10 adet), halkahâ-i bâb kullâblu (20 adet, fî 6, kıymet 120) kıymet $350^{75}$. Menteş Yahudi eliyle alınan muşamma' (10 kit'a, fî 240, kıymet

71 TS.MA.d 35-0-0, 29.08.1025/11.09.1616, v. 243a.

72 TS.MA.d 35-0-0, 29.08.1025/11.09.1616, v. 159a.

73 Muşamma' (muşamba): Su geçirmeyecek bir hale koymak üzere, bir tarafina kauçuk veya plastik bir madde sürülerek hazırlanan ve yaygı olarak kullanılan örtü gereci. Doğan Hasol, Ansiklopedik Mimarlk Sözlï̈̆̈̈, İstanbul 1998, s. 325; Aziz Doğanay, Klasik Devir Osmanl Hanedan Türbeleri 15221604, İstanbul 2009, s. 425. Arapça şem’ kökünden gelen müşemma' kelimesi, 17. yüzyll başı itibariyle mumlanarak hazırlanan ve cam yerine soğuğu kesmek için kullanılan yapı malzemesi olarak kullanılmıştır.

74 TS.MA.d 35-0-0, 29.08.1025/11.09.1616, v. 189a, 218b, 244b.

75 TS.MA.d 35-0-0, 29.08.1025/11.09.1616, v. 189a. Kullâb = Güllap: İki uzun demir parçanın ortasından birbirine geçerek kıvrılması, eklem noktasından sonra da yan yana gelerek çift katlı bir kesit oluşturması şeklinde yapılan ve uçlara doğru sivrilen, demircilerin yaptı̆̆ı bir tür menteşe. Geleneksel Türk evlerinin kapı, pencere ve dolaplarında kapağın kasaya tutturulması ile açılıp kapanmasını sağlamak amacıyla kullanılır. Genellikle, ahşap kesitine açılan bir delik içine yerleştirilerek çakılır ve arka yüzeye çıkan uçlan iki yana yatırılıp -çıkıntı yapmaması için- tekrar tahtaya gömülür. Parçalan, (kullâb haline getirilmeden) tek olarak da -içine halka yerleştirilmiş bir tespit elemanı gibi- yaygın şekilde kullanılmışır. Bu elemanı, çakma ahşap kapılardaki halkalı demir kabaralar veya metal rozetleri, merkezlerinden kapağa çakan iri başlı bir çivi gibi düşünmek mümkündür. İsa Gıda, İstanbul Bayezid Camii Tass Süslemeleri, Marmara Üniversitesi Türkiyat Araştırmaları Enstitüsü Yüksek Lisans Tezi, İstanbul 2005, s. 120. 
2.400), mismâr-1 muşamma' (9.000 adet, beher 1.000 fî 30, klymet 270) cami pencerelerinde kullanılmıştır. Köşebend, halka, mandal ve çivi kullanılarak kullâblı (menteşeli) muşambaların pencere kasalarına yerleştirildiği anlaşılmaktadır. Osmanlı dini mimarisinde klasik dönem uygulamalarının devamı olarak büyük ölçüde camlar yerine dış etkenlere karşı dayanıklı olması nedeniyle alt kat nizami pencerelerinde muşamba kullanılmışır ${ }^{76}$.

Yine inşa evrakından rûznamçede Osman Bâşe eliyle minare kapıları, dolaplar ve dolma ve cami-i şerif çerçeveleri için gerekenlerle birlikte ücretler hakkında birtakım bilgiler verilmektedir. 29.04.1025/16.05.1616 tarihli bu kayıtta da yine aynı dönemde tamamlanan ve ücretleri ödenen işler şu şekilde yer almaktadır:

Cami-i şerif alt kat çerçeveleri (48 adet, 800 Akçe'den 38.400 Akçe)

Cami-i şerifin üst tabakası çerçeveleri (29 adet, 700 Akçe'den 20.300 Akçe)

Kasr-1 hümâyûnun dolap kaplamaları (1 adet, 3.000 Akçe)

Kasr-1 hümâyûnun çerçeveleri (4 adet, 400 Akçe'den 1.600 Akçe)

Minare kapıları kaplamaları (2 adet, 5000 Akçe'den 10.000 Akçe)

Toplam 73.300 Akçe

Mimar Ağa tezkiresine Devlet, Hacı Ali ve Üstad Hasan eliyle cami-i şerifteki pâdişâh mahfili için sadefkârî pencereler, haremin engüşt pencereleri ile sadefkârî ve devvom pencerelerin kaplaması için gerekenlerle ustalık ücretleri de kaydedilmiştir. Buna göre 11 adet devvom sedefkârî pencereler için 25.000 Akçe'den 275.000 Akçe, 46 adet, engüşt harem pencereleri için 10.000 Akçe'den 460.000 Akçe, padişah mahfili için 2 adet sedefkârî pencerelere 20.000 Akçe'den 40.000 Akçe ödenmiştir. Kubbeci, çilingir ve diğer malzemelerle toplam 775.000 Akçe masraf edilmiştir.

Bahsi geçen kayıtta, Osman Bâşe'nin eliyle cami ve hünkâr kasrı pencerelerinin çerçeveleri, minare kapıları ile hünkâr kasrı dolap kaplamalarının yapıldığı belirtilmektedir. Osman Bâşe'nin bu durumda kapı ve pencere çerçevelerini (kasaları) yaptığı anlaşılmaktadır. Devamında mimar ağa tezkiresine göre, künde ve sedef işleriyle ilgilenen ustaların isimleri de Devlet, Hacı Ali ve Üstad Hasan olarak geçmektedir. Kündekârî ve sedefkârî tüm pencerelerin kaplamasında çalışan bu grup, tezyinat işiyle uğraşan ve işleri karşılı̆ğ en çok ödemenin yapıldığı işçiler olarak dikkati çekmektedir.

76 Aziz Doğanay, Mimari ve Tezyini Unsurlaryyla Câmi, Diyanet İşleri Başkanlığı Yayınları, Ankara 2017, s. 145 . 
İnşa evrakında künde ve sedef ustalarının görev tanımlarında bulunan pencerelerin ise işçilik olarak sedefkârî, devvom sedefkârî ve engüş̧ harem pencereleri olmak üzere üç bölümde değerlendirildiği görülmektedir. Sedefkârî pencereler, padişah mahfilinde olduğu belirtilen sedef işçiliği ile öne çıan, en çok emek ve kaynak sarf edilen pencerelerdir. Devvom sedefkârî ise, Farsça'da ikinci anlamına gelen devvom ile sedef işşiliği vurgulanan sedefkârî kelimeleriyle oluşturulmuş, sayı itibariyle mihrab duvarındaki alt kat nizami pencerelerle tutarlı bir sedef işçiliği terimidir ${ }^{77}$. Nitekim padişah mahfili tezyinatın yoğunluğuna göre önem sırasında öncelik arz etmesi, ayrıca pencere büyüklüğü vb. açllardan daha dar bir alan teşkil ettiği için daha incelikli ve karmaşık tekniklerin kullanıldığı görülür. Ayrıca malzeme de daha çeşitli ve kalitelidir. Mihrab duvarındaki pencere kanatları ise, hünkâr mahfilindekilere nazaran derinlik, malzeme ve teknik açıdan daha farklıdır ve ikinci derece olarak düşünülüp uygulanmış olabilir. Bu konuda, kaynaklarda herhangi bir bilgiye ulaşılamamıştır.

Engüsst pencereler ise, yine kelime kökeninden hareketle parmaklıklı pencereleri tanımlıyor olabilir ${ }^{78}$. Sayısı mihrab duvarındaki pencerelerin haricindeki alt kat pencereleri ile tutarlı bu kullanımın, görsel bir kanıt olmamakla birlikte ahşap yapıldığı belirtilen, alt katta ve muşamba pencerelerin sabitlenmesi, korunması ve hatta ışı̆̆ın geçirgenliği gibi faktörleri olumlu etkileyecek kafes, şebeke veya parmaklık olması tutarlıdır. Yazılı kaynaklarda engüşt pencere ifadesine rastlanmamaktadır. Fakat bu ifadenin kelime kökü ve yapıldığı belirtilen malzeme itibariyle ahşap parmaklık yahut kafes olabileceği düşünülebilir. Bu konuda ahşap dikey değişik şekillerde yapılmış farklı örneklere tarihi dini mimari örneği bazı camilerde rastlanmaktadır. Giresun'da tahtalı Camiii ${ }^{79}$, parmaklık şeklinde ahşap pencereleri; Kastamonu Çağlar Köyü Merkez Camiï ${ }^{80}$ ahşap kafesleri ile dikkat çekmektedir. Sivil mimari örneği ahşap yapılarda ${ }^{81}$ ve ahşap camilerde ${ }^{82}$ örneklerine

77 Devvom, dovvom: İkinci. Mehmet Kanar, Farsça Türkçe Sözlük, İstanbul 2000, s. 558.

78 Engüşt: Kömür, parmak. Mehmet Kanar, Farsça Türkçe Sözlük, s. 726-727.

79 Eyüp Nefes, "Giresun'da Yeni Tesbit Edilen Bir Ahşap Camii; Çaldağ Beldesi Melikli Mahallesi Tahtalı Camii”, Din Bilimleri Akademik Araştırma Dergisi, C IX/S. 3, Samsun 2009, s. 192-205.

80 Yılmaz Can, "Kastamonu ve Sinop Yöresinde Bulunan Ahşap Camiler”, Ondokuz Mayıs Üniversitesi Ilahiyat Fakültesi Dergisi, İstanbul 2003, s. 117-134.

81 Oya Şenyurt, "İnşa Kuralları, Mimari Algı ve Mekân Kullanımı Bağlamında Osmanlı Toplumunda Cumba/Şahnişin”, Mimarlk ve Taşam Dergisi, G I/S. 1, 2016, s. 88. Yusuf Çetin, "Geleneksel Türk Evinde Cumba", Sanat Tarihi Dergisi, C XXV/S. 2, (2006), s. 21-25.

82 Yılmaz Can, "Samsun'da Bulunan İki Önemli Ahşap Eser Gökçeli ve Bekdemir Camileri”, Mimari ve Kültürel Miras, Efsane, Dil, Sanat, Edebiyat ve Siyaset, ed. Cevdet Yılmaz, Samsun 2013, 
rastladığımız ahşap parmaklık yahut kafes; büyük camların kullanımının mümkün olmadığı dönemlerde muşamba ile birlikte kârgir camilerde de kullanılmış olabilir. $\mathrm{Bu}$ konuda son kalan örnekleri destekleyen arşiv kayıtlarına ihtiyaç vardır. Fakat 16. yüzyılda inşa edilen Süleymaniye Külliyesi inşa defterlerinde pencere çeşitleri kündekârî, müfettah (açılan), dû-rûy (çift taraflı), kürre-çatma olarak zikredilmektedir $^{83}$. 18. yüzyılda inşa edilen Laleli ve Nuruosmaniye Külliyeleri inşa evraklarını ele alan çalışmalarda ise bu konuda herhangi bir mevcut değildir ${ }^{84}$.

Sultan Ahmed Camii’nde orta tablası geniş üçer tablalı kapı kanatları ve pencere kapaklarının klasik dönem ahşap işlerinin yapılmaya devam edildiğini göstermektedir ${ }^{85}$. Sultan Ahmed Camii kapı kanatları ve pencere kapaklarında üst üste oturtulmuş dikdörtgen ve karelerden gelişmiş kündelerden oluşan örnekler görülmektedir. Bu tarz kündekârî tekniği ile klasik dönemin önceki yüzyılda yapılan çalışmalardaki çeşitlilik ve denemelerin süregeldiğini ortaya koymaktadır ${ }^{86}$. Özellikle Sultan Ahmed Camii kapı kanatları ve pencere kapaklarındaki kündekârî çalışmalarında hendesî tezyinatın sonsuzluk hissi uyandıran kompozisyon çeşitlemeleri, bugörüşüdesteklemektedir ${ }^{87}$. Belgelerleilgilidikkatiçekenbirdurumda, Süleymaniye inşasında her bir pencere ve kapının kasa ve kanatlarını yapan ustalar ile ilgili detaylı bilgiler verilirken; Sultan Ahmed Camii inşasını ele alan ruznamçede böyle bilgilerin yer almamasıdır ${ }^{88}$. Sultan Ahmed Camii vâridât ve masârif defterinde inşa sürecinde neccârânın yaptığı işler bu işler için yapılan ödemeler tablo 8'de yer almaktadır.

s. 26-33.

83 Ömer Lütfi Barkan, Süleymaniye Cami ve İmareti İnsaatı, C II, Ankara 1972, s. 120.

84 Aras Neftçi, Laleli Kïlliyesi’nin İnşaat Süreci, İstanbul Teknik Üniversitesi Sosyal Bilimler Enstitüsü Doktora Tezi, İstanbul 2002, s. 124-125; Osman Taşkın, Nuruosmaniye Külliyesi’nin Fizikî, İdar̂, Malı ve Sosyo-Ekonomik Yapısı, Mimar Sinan Güzel Sanatlar Üniversitesi Sosyal Bilimler Enstitüsü Doktora Tezi, İstanbul 2007, s. 75-76.

85 Hatice Örcün Barışta, Osmanh İmparatorluğu Dönemi İstanbul Cami ve Türbelerinde Ağaç İ̧leri, AKMB Yayınları, Ankara 2009, s. 439.

86 Barışta, Osmanl İmparatorluğu Dönemi İstanbul Cami ve Türbelerinde Ağaç İsleri, s. 167.

87 Barışta, Osmanl İmparatorluğu Dönemi İstanbul Cami ve Türbelerinde Ağaç İsleri, s. 179-180.

88 Ömer Lütfi Barkan, Süleymaniye Cami ve İmareti İnşaat, C II, Ankara 1972, s. 101-121. Süleymaniye inşa defterlerinde kapı kanatlarından pencere kapaklarına kadar tüm çalışanların ismi geçmektedir, en önemli ustalar ise Süleyman b. Davud, Yahyâ, Bosnalı Hasan ve Hamza Sefer'dir. 
Tablo 8: Sultan Ahmed Külliyesi inşasında çalışan Neccârân görevleri ve ücretleri

\begin{tabular}{|c|c|c|c|}
\hline \multicolumn{4}{|c|}{ Ücret-i neccârân } \\
\hline \multicolumn{4}{|c|}{ Bahâ } \\
\hline \multicolumn{4}{|c|}{ Doksan üç yük elli dokuz bin dokuz yüz yetmiş iki Akçe } \\
\hline \multicolumn{2}{|c|}{ Der-zamân-1 Hüseyin Ağa ve İdris Ağa } & \multicolumn{2}{|c|}{ Der-zamân-1 Kalender Paşa } \\
\hline \multicolumn{2}{|r|}{ Bahâ } & \multicolumn{2}{|c|}{ Bahâ } \\
\hline \multicolumn{2}{|c|}{26 yük 33.442 Akçe } & \multicolumn{2}{|c|}{67 yük 26530 Akçe } \\
\hline \multicolumn{2}{|r|}{ Berây-1 } & Berây-1 & Berây-1 \\
\hline \multicolumn{2}{|c|}{$\begin{array}{l}\text { Sahten-i kasr-1 hümâyûn der saray-1 } \\
\text { İbrahim Paşa ve hımam-1 saray-1 mezbûr }\end{array}$} & $\begin{array}{l}\text { Hedm-i Saray-1 } \\
\text { Ahmed Paşa der- } \\
\text { zamân-1 Kalender } \\
\text { Paşa }\end{array}$ & $\begin{array}{l}\text { Sahten-i Karaçav } \\
\text { ve karhane ve } \\
\text { hedm-i bazı } \\
\text { ebniye-i köhne }\end{array}$ \\
\hline \multicolumn{2}{|r|}{ Bahâ } & Bahâ & Bahâ \\
\hline \multicolumn{2}{|c|}{ 85.534 Akçe } & 28.688 Akçe & 54.323 Akçe \\
\hline $\begin{array}{c}\text { Der-zamân-1 } \\
\text { Hüșeyin } \\
\text { Ağga ve İdris Ağa } \\
\end{array}$ & $\begin{array}{l}\text { Der-zamân-1 } \\
\text { Kalender Paşa }\end{array}$ & & \\
\hline Bahâ & Bahâ & & \\
\hline 23.643 Akçe & 56.891 Akçe & & \\
\hline Berây-1 & Berây-1 & \multicolumn{2}{|c|}{ Berây-1 } \\
\hline \multicolumn{2}{|c|}{ 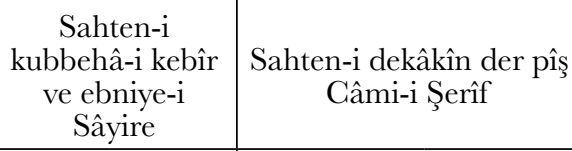 } & \multirow{2}{*}{\multicolumn{2}{|c|}{$\begin{array}{l}\text { Sahten-i odahâ-i cedide der pîş-i } \\
\text { mihrap ve der saray-1 Mehemmed Paşa }\end{array}$}} \\
\hline $\begin{array}{l}\text { Der-zamân-1 } \\
\text { Hüseyin Ağa ve } \\
\text { İdris Ağa }\end{array}$ & $\begin{array}{l}\text { Der-zamân-1 } \\
\text { Kalender Paşa }\end{array}$ & & \\
\hline Bahâ & Bahâ & Bah & \\
\hline $\begin{array}{l}215.990 \\
\text { Akçe }\end{array}$ & 559.592 Akçe & 11 yük 55 & 312 Akçe \\
\hline & & $\begin{array}{l}\text { Der-zamân-1 Hüseyin } \\
\text { Ağa ve İdris Ağa }\end{array}$ & $\begin{array}{l}\text { Der-zamân-ı } \\
\text { Kalender Paşa }\end{array}$ \\
\hline & & Bahâ & Bahâ \\
\hline & & 5 yük 98.590 Akçe & 5 yük 56.722 Akçe \\
\hline
\end{tabular}




\begin{tabular}{|c|c|c|c|c|}
\hline Berây-1 & \multicolumn{2}{|c|}{ Berây-1 } & \multicolumn{2}{|r|}{ Berây-1 } \\
\hline $\begin{array}{l}\text { Neccârân ve } \\
\text { sengtrâşân } \\
\text { rıhtım ve } \\
\text { divarhâ ve } \\
\text { şadırvan }\end{array}$ & \multicolumn{2}{|c|}{$\begin{array}{c}\text { Neccârân ve haddâdân-1 } \\
\text { yolmacyyân }\end{array}$} & \multicolumn{2}{|c|}{ Neccârân gündelikciyân } \\
\hline $\begin{array}{l}\text { Der zamân-1 } \\
\text { Kalender } \\
\text { Paşa }\end{array}$ & \multicolumn{2}{|c|}{ Der anbar } & \multicolumn{2}{|c|}{ Ber mûceb-i defter-i müfredât } \\
\hline Bahâ & \multicolumn{2}{|c|}{ Bahâ } & \multicolumn{2}{|r|}{ Bahâ } \\
\hline \multirow[t]{4}{*}{ 25.330 Akçe } & \multicolumn{2}{|c|}{ 212.166 Akçe } & \multicolumn{2}{|c|}{69 yük 29.801 Akçe } \\
\hline & $\begin{array}{l}\text { Der-zamân-1 } \\
\text { Hüseyin Ağa }\end{array}$ & $\begin{array}{l}\text { Der- } \\
\text { zamân-1 } \\
\text { Kalender } \\
\text { Paşa }\end{array}$ & $\begin{array}{c}\text { Der-zamân-1 Hüseyin } \\
\text { Ağa }\end{array}$ & $\begin{array}{l}\text { Der-zamân-1 } \\
\text { Kalender Paşa }\end{array}$ \\
\hline & Bahâ & Bahâ & Bahâ & Bahâ \\
\hline & 43.126 Akçe & $\begin{array}{l}169.040 \\
\text { Akçe }\end{array}$ & 16 yük 53.857 Akçe & 52 yük 75.944 Akçe \\
\hline $\begin{array}{l}\text { Berây-1 Döşeme } \\
\text { ve tuğla-i } \\
\text { dekâkîn }\end{array}$ & \multicolumn{2}{|c|}{$\begin{array}{c}\text { Berây-1 } \\
\text { Sahten-i divâr-1 cedîde } \\
\text { mea seng-i moloz ve } \\
\text { 1rgadiye der saray-1 } \\
\text { Mehemmed Paşa }\end{array}$} & \multicolumn{2}{|c|}{$\begin{array}{l}\text { Berây-1 } \\
\text { Sahten-i hâne-i kebîr ve odahâ-i Ayişe } \\
\text { Sultan }\end{array}$} \\
\hline $\begin{array}{l}\text { Der-zamân-1 } \\
\text { Hüseyin Ağa ve } \\
\text { İdris Ağa }\end{array}$ & \multicolumn{2}{|c|}{$\begin{array}{l}\text { Der-zamân-1 Hüseyin } \\
\text { Ağa ve İdris Ağa }\end{array}$} & \multicolumn{2}{|c|}{ Der-zamân-ı Hüseyin A ̆ga ve İdris Ağa } \\
\hline Bahâ & \multicolumn{2}{|c|}{ Bahâ } & \multicolumn{2}{|c|}{ Bahâ } \\
\hline 5.520 Akçe & \multicolumn{2}{|c|}{ 44.484 Akçe } & \multicolumn{2}{|c|}{52.132 Akçe } \\
\hline
\end{tabular}

Tablo 8'de yıkım, yapım ve tamir işlerinde; seng-traşan ve yolmacıyân haddâdân ile çalışan neccârlar yer almaktadır. İçlerinde gündelikçiler de bulunan bu işçi grubunun özellikle inşa sahasının hazırlanması için sarayların yıkıldığı dönemde ve sonra karaçav (iskele) ve rıhtım inşasında görev aldıkları görülmektedir. İnşa sürecinde kullanılacak anbar vb. yapıların da inşa ve tamirinde çalışmışlardır. Ayrıca başta İbrahim Paşa Sarayı ve hamamı olmak üzere külliye yapılarının inşasında da çalıştıkları görülmektedir. 


\section{Değerlendirme ve Sonuç}

Sultan Ahmed Külliyesi inşa sürecinde yapının içinde ve dişında pek çok ahşap yapı malzemesi kullanılmıştır. Kullanıldıkları yerler sebebiyle inşaatta iskele, hatıl gibi bölümlerde bugün doğrudan incelemek mümkün olmazken; kapı kanatları, pencere ve dolap kapaklarında ve cami tefrişatında kullanılan mobilyalarda ahşap yapı malzemelerini izleyebilmekteyiz.

$\mathrm{Bu}$ malzemeler Erre-keşân sınıfı ile kesilip, devrilerek inşaata getirilirken; Neccârân bunları inşaata hazır hale getiren ve kullanan sınıf olmuştur. Mirî ve şahsi esirlerden ve şehirlerden getirilen ustalardan müteşekkil bu sınıflar, inşa sürecinde pek çok görev üstlenmişlerdir. İnşa programında sayı olarak dikkat çeken bu gruplar, liste halinde tek tek belirtilmezken; cami tezyinat programının bir parçası olan ve işin zanaat boyutundan ziyade sanat kısmı ağır basan sedefkârî ustalarının isimleri ve işleri bizzat rûznamçede yer almaktadır.

Sultan Ahmed Külliyesi'nin özellikle pencere ve kapılarında kullanılan ceviz ve şimşir levhalar ile ceviz, şimşir, fistık çamı tomruklarının alınması ve işlenmesi hususunda evrakta adı geçen bazı görevliler vardır. Bunlar Üstad Hasan, Mehmed Bevvâb, Kara Halife, İskender, Hüsrev, Keyvan, Müslim, Mehmed Çelebi, Menteş Yahudi, Arslan Reis, Mehmed Bevvâb, Mahmud Bevvâb, Mehmed Bâşe, İskender Bâşe, Mustafa Efendi, Topçu Dive, Turhan Ağa, Mustafa Ağa, Ali Bâşe, Ramazan Reis, Karaca Turgut, Ahmed Çelebi, Dimitri, solak İbrahim Çelebi, Bodur Cafer ve Kasım'dır. En çok tekrar eden ve ünvanı olan isim Üstad Hasan dikkat çekmektedir. Bu durum onun erre-keşân üstadı olabileceği ve ehl-i hirefi temsil ediyor olabileceğini düşündürmektedir.

Neccâr/Neccârân ise, ahşap malzeme ve kaplama kullanarak binâların iç ve dış aksamını ahşap malzemeler ile kaplayan; kapı, pencere, dolap, merdiven, pano, kepenk, kapak vb. yapan ve takan işçiler grubudur. Sultan Ahmed Camii merkezli külliyenin inşa sürecinden günü gününe bahsedilen rûznamçede neccâran işçi grubunun işleri ile ilgili 198 kayıt mevcuttur. Sayıları zaman zaman 600'ü bulan neccârân, esirân-1 mîrî, esîrân-1 forsa, esîrân-1 Ali Paşa, Esîrân-1 Sadrazam Mehmed Paşa ve vardiyeli olmak üzere birkaç sınıftan oluşuyordu. Köstendil, Midilli, Gelibolu, Selanik, adalar, Filibe, Sofya, Molova, Amasya, Köstendil, Bihlişte, İvranya, Edirne, İmroz, gibi yerlerden ustalar getirilerek kalifiye elemanı arttırılan bu grubun içinde üstadlar, sayıları 35’i bulan neccâr halifeleri ve şakirtleri mevcuttur. 
İnşa sürecinde neccârân sınıfinın fazla sayıda ve görevde yer almasının sebebi kapı kanatları, dolap ve pencere kapakları vb. ahşap yapı elemanlarının serbest piyasadan hazır olarak alınmayarak ahşap malzemelerinin atelyelerde istenen ölçülerde üretilmesi sayllabilir. Rûznamçe defterindeki alımlar bu durumu destekler niteliktedir. Ayrıca mimar tezkiresiyle neccârânın inşa sahasında atıl vaziyetteki imam evi, duvarlar gibi yapıların yıkılmasında da görev aldığı ve geri dönüş̧ürülecek malzemeyi çıardıkları inşa rûznamçesinde geçmektedir. Ayrıca Maltepe iskelesi ve Şühûd kapısındaki kereste ambarının tamirini de kalfalarıyla birlikte neccârânın yaptığı kaydedilmiştir.

Caminin cam çerçeveleri için karaağaç levhalar temin edildiği, bunların ustalar tarafindan özel ölçülerde hazırlandığı belgelerde yer almaktadır. Yine bu pencere kapakları ve kapı kanatlarını kaplamak için özellikle ceviz ve şimşir levhalar temin edilerek, ustaların işçiliğiyle kaplandığı belirtilmektedir. Ayrıca kündekârî ve sedef iş̧̧iliği olan ahşap yapı elemanlarının tezyinatında ceviz, pelit, şimşir, findık, kestane, abanoz ve "çûb-ı cevherdârî" şeklinde ifade edilen fakat detay verilmeyen nadir ağaçların kullanıldığı görülmektedir.

En çok kullanılan ahşap malzemeler, ceviz, köknar, karaağaç gibi sütun, taban ve mobilya yapılan dayanıklı ağaçlardan elde edilmiştir. Süleymaniye Külliyesi inşasında kullanılan ceviz, verdinar (köknar), şimşir, çınar, fındık, gürgen, pelit karaağaç ve gülgen (beyaz kayın) den farklı olarak ladin, fistık çamı, kızılcık, findık, çam, kestane, abanoz, çûb-ı cevherdârî, elvah-ı sefine ve ahşab-ı köhne kullanılmıştır. Deniz ve kara yolundan ulaşımını hem inşa görevlileri hem de sorumlularının gerçekleştirdiği bu malzemeler, ambarlarda depolanarak terbiye edildikten sonra, atelyelerde işlenerek kullanılmıştır. Es'ar defterlerinden ve klasik dönem ebatlarından farklı ebatlarda kullanılan malzemeler için önemli miktarda kalifiye iş̧̧iye ihtiyaç duyulmuştur. Anadolu ve Rumeli'nin farklı yerlerinden getirilen ustalar, bu alandaki eksikliği tamamlamıştır.

Ahşap malzemeler klasik ölçülerden, büyük olduğundan, piyasadan temininde sıkıntı yaşanmış ve bu nedenle hazır malzeme kullanmak mümkün olmamışır. $\mathrm{Bu}$ yüzden es'ar defterlerinden farklı ebatta ahşap malzeme bilgisi arşiv kayıtlarında yer almıştır. Çok sayıda işçi kullanmak için özellikle daha az ücret alan ve daha çok iş yapan esirlerden faydalanıldığı da görülmektedir. Bu yüzden olsa gerek, tüm işçilerin isimlerine detaylı bir şekilde yer verilmemiş, sadece büyük ödemeler ve sanatlı işler hakkında bazı isimler ön plana çıkarılmıştır. Padişah mahfili, dolap, pencere kanatları ve kapılar gibi dikkati ilk çeken yerlerde yoğunlaşan sedef işçiliğinde Üstad Hasan, Hacı Ali ve Devlet isimleri verilen sanatçılardır. 
Sengtraş Konyalı Mustafa'nın da mahfil pencerelerinde özellikle bademler ve yuvaları için çalışmış olabileceği ve Osman Bâş̧e'nin de kapı kanatları ile pencere ve dolap kapaklarını takmak için gereken çerçevelerin (kasa) yapımında görev aldığı görülür.

Ahşap ve ahşapta sedef işçiliğiyle ilgili inşa evrakında yer alan devvom, engüş̧ gibi terimler 17. yüzyıl inşa tercih ve tekniklerini anlamamız açısından önemlidir. 16. yüzyıl Süleymaniye Külliyesi, 18. yüzyıl Laleli ve Nuruosmaniye Külliyesi gibi çalışmalarla klyaslandığında bu ifadelerin henüz yerleşmiş karşlıklarının bulunmadığı tespit edilmiştir. Bugün orijinal örneklerini bulamadığımız ve arşiv çalışmaları olmadan takip edemediğimiz bu pencere çeşitlerinin literatüre kazandırılması gerekmektedir. Bu yüzden dönemin inşa, malzeme ve teknik terimleri konusunda hem arşiv hem de sanat işçiliği temelli daha çok araştırmaya ihtiyaç duyulduğu açıtır.

Ahşap işçiliği açısından, klasik dönemin izlerinin takip edildiği ve özellikle bugün geçirdiği yangın vs. tahribat sonrası izleyemediğimiz hünkâr kasrı gibi klasik dönem külliyelerinden daha fazla yapı ile planlanmış Sultan Ahmed Külliyesi'nde künde ve sedef işlerinin oldukça fazla ve özenli olduğu görülmektedir. Süleymaniye Camii'ne benzer bir organizasyon ile ele alınan Sultan Ahmed Camii inşasında, ahşap malzemelerin kullanım alanları ve ahşap tezyinatın yoğunluk yerleri genel teamüle uygun olup, hacim nedeniyle daha büyük ebatlı ve daha çok ahşap malzemenin kullanımı söz konusudur.

Bu yüzden erre-keşân denilen ağaç devirme göreviyle meşgul iş̧̧ilerin, reis denilen tersane kaptanlaryyla birlikte Sinop, Giresun, Trabzon, Ada-i cedide vb. yerlerden deniz yoluyla çok miktarda levha, tomruk ve kereste getirdiği görülmektedir. Sultan Ahmed Külliyesi'nde bugün neredeyse yok olan Karaağaç gibi dayanıklı ağaçları kapsayan çok miktarda ahşap malzeme, malzeme ve teknik üstünlüğü ile kullanılmıştır ve bugün de bu başarılı yapıyı kuvvetlendirmeye ve güzelleştirmeye devam etmektedir. 


\section{KAYNAKLAR}

\section{Arşiv Kaynakları}

BOA. D. 00040.001

BOA, D.00211.001.00.

TS.MA.d 35-0-0, 29.08.1025/11.09.1616, v. 8a, 11a, 14a, 15b, 18b, 19b, 22a, 22b, 23b, 28b, 29a, 33a, 34a, 48a, 56b, 64b, 79b, 82b, 85a, 108b, 110b, 115b, 127a, 127b, 145b, 160b, 169a, 175b, 176b, 189a, 190a, 194a, 196b, 197b, 229a, 232a, 233a, 233b, 243a, 244a.

\section{Araştırma ve İnceleme Eserler}

Ahmet Refik, Hicri Onikinci Asırda İstanbul Hayatr, İstanbul 1930.

Arseven, Celal Esat, Sanat Ansiklopedisi, C II, Milli Eğitim Basımevi, İstanbul 1947.

Barışta, Hatice Örcün, Osmanh İmparatorluğu Dönemi İstanbul Cami ve Türbelerinde Ağaç İsleri, AKMB Yayınları, Ankara 2009.

Barkan, Ömer Lütfi, Süleymaniye Cami ve İmareti İņsaat, C I-II, Türk Tarik Kurumu Yayınları, Ankara 1972.

Cafer Efendi, Risâle-i Mimâriyye, haz. İ. Aydın Yüksel, İstanbul Fetih Cemiyeti, İstanbul 2005.

Can, Yılmaz, "Samsun'da Bulunan İki Önemli Ahşap Eser Gökçeli ve Bekdemir Camileri”, Mimari ve Kültürel Miras, Efsane, Dil, Sanat, Edebiyat ve Siyaset, ed. Cevdet Yllmaz, Samsun 2013, s. 26-33.

Can, Yılmaz, "Kastamonu ve Sinop Yöresinde Bulunan Ahşap Camiler", Ondokuz Mayıs Üniversitesi Illahiyat Fakültesi Dergisi, S. 14, (2003), s. 117-134.

Gıda, İsa, İstanbul Bayezid Camii Taşs Süslemeleri, Marmara Üniversitesi Türkiyat Araştırmaları Enstitüsü Yüksek Lisans Tezi, İstanbul 2005.

Çelik, Serpil, Mevcut Belgeler Işı̆ğnda Süleymaniye Külliyesinin Yapım Süreci, İstanbul Teknik Üniversitesi Fen Bilimleri Enstitüsü Doktora Tezi, İstanbul 2001.

Çelik, Serpil, Süleymaniye Külliyesi, Malzeme, Teknik ve Süreç, Atatürk Kültür Merkezi Yayınları, Ankara 2009. 
Çetin, Yusuf, "Geleneksel Türk Evinde Cumba", Sanat Tarihi Dergisi, C XXV/S. 2, (2006), s. $18-27$.

Doğanay, Aziz, Mimari ve Tezyini Unsurlanyla Câmi, Diyanet İşleri Başkanlığı Yayınları, Ankara 2017.

Doğanay, Aziz, Klasik Devir Osmanl Hanedan Türbeleri 1522-1604, Klasik Yayınları, İstanbul 2009.

Hasol, Doğan, Ansiklopedik Mimarlı Sözlüğü, İstanbul 1998.

Kanar, Mehmet, Farsça Türkçe Sözlük, İstanbul 2000.

Kolay, İlknur Aktuğ, "Ayazma Camisi İnşaat Defteri”, 9. Milletlerarası Türk Sanatlar Kongresi Bildiriler (23-27 Eylül 1991), G I, T. C. Kültür Bakanlığı Yayınları, Milli Kütüphane Basımevi, Ankara 1995.

Kolay, İlknur Aktuğ, "Osmanlı Belgelerinde Yer Alan Bazı Ahşap Yapı Malzemesi Üzerine Düşünceler”, Sanat Tarihi Defterleri, S. 10, İstanbul 2006.

Kolay, İlknur Aktuğ, "XVI. Yüzyılda Kullanılan Bazı Inşaat Malzemeleri ve Kullanım Yerleri”, 16. Yüzynlda Türk ve Islam Bilim ve Teknolojisi Sempozyum Bildiri Kitapçı̆, İTÜ Mimarlık Fakültesi, İstanbul 1986.

Kolay, İlknur Aktuğ-Çelik, Serpil, "Malzeme ve Teknoloji”, Bir Şaheser Süleymaniye Külliyesi, ed. Selçuk Mülayim, Ankara 2007.

Kolay, İknur Aktuğ-Ersen, Ahmet, "Bir 15. Yüzyıl Yapısı Olan Tahtakale Hamamı'nda Uygulanan Bazı Yapım Teknikleri’, Taç Vakfı Yillı̆̆ı, S. 1, İstanbul 1991.

Kütükoğlu, Mübahat S., Osmanllarda Narh Müessesesi ve 1640 Tarihli Narh Defteri, İstanbul 1983.

Mehmet, Salahi, Kamus-ı Osmani, Kanaat Kitabevi, İstanbul 1313.

Neftçi, Aras, Laleli Külliyesinnin İşaat Süreci, İstanbul Teknik Üniversitesi Sosyal Bilimler Enstitüsü Doktora Tezi, İstanbul 2002.

Öngül, Ali, "Tarih-i Câmi-i Nuruosmânî”, Vakıflar Dergisi, S. 24, Ankara 1994.

Öten, Aliye, Arşiw Belgelerine Göre Sultan Ahmed Camii ve Inşası, Marmara Üniversitesi Sosyal Bilimler Enstitüsü Doktora Tezi, İstanbul 2017. 
Peynircioğlu, H. - Toğrol E. - Aksoy İ. H., "İstanbul'da Osmanlı Döneminde İnşa Edilen Camilerin Temelleri”, Uluslararası Türk-İslam Bilim ve Teknoloji Tarihi Kongresi 14-18 Eylïl 1981, C III, İstanbul 1981.

Şenyurt, Oya, "İnşa Kuralları, Mimari Algı ve Mekân Kullanımı Bağlamında Osmanlı Toplumunda "Cumba"/"Şahnişin"”, Mimarlk ve Taşam Dergisi, C I/S. 1, 2016, s. 87-103.

Taşkın, Osman, Nuruosmaniye Külliyesinnin Fizikî, İdarî, Malî ve Sosyo-Ekonomik Yapısı, Mimar Sinan Güzel Sanatlar Üniversitesi Sosyal Bilimler Enstitüsü Doktora Tezi, İstanbul 2017.

Yüceil, Yaşar, Osmanl Ekonomi-Kültür-Uygarlk Tarihine Dair Bir Kaynak Es'âr Defteri (1640 Tarihli), Türk Tarih Kurumu Basımevi, Ankara 1992.

TDK (www.sozluk.gov.tr) 


\section{EKLER}

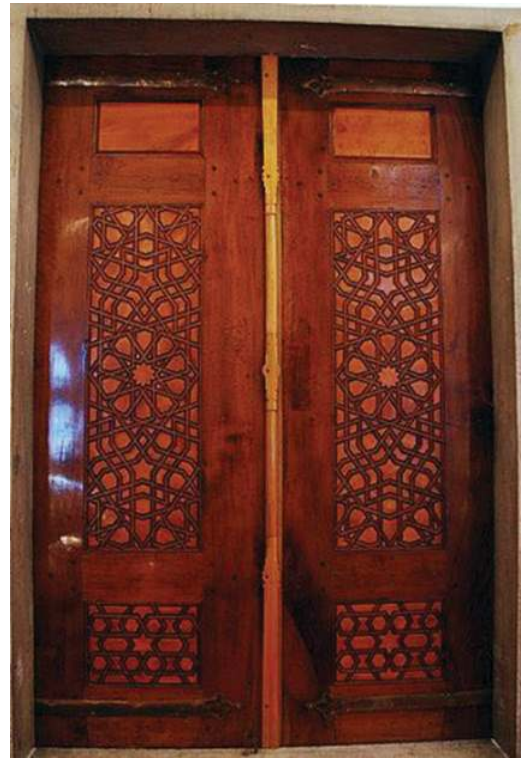

Ek 1: Sultan Ahmed Camii üst mahfel kündekârî bir pencerenin kanatları

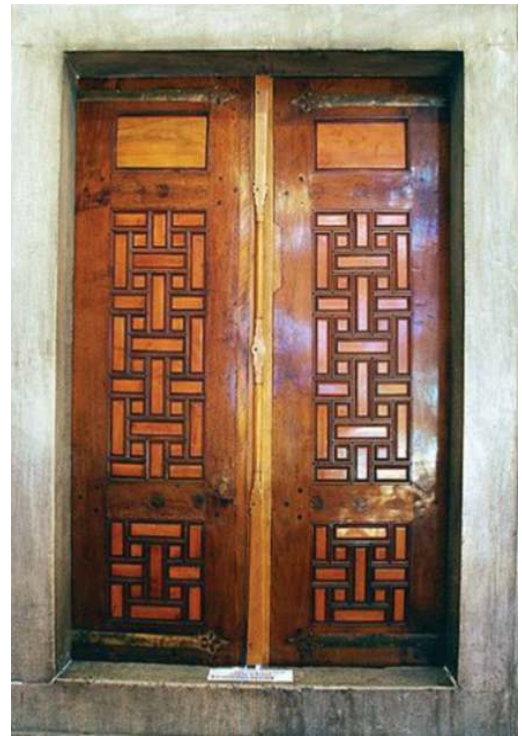

Ek 2: Sağdaki Sultan Ahmed Camii alt kat kündekârî bir pencerenin kanatları

Belleten, Nisan 2021, Cilt: 85/Sayı: 302; 53-94 


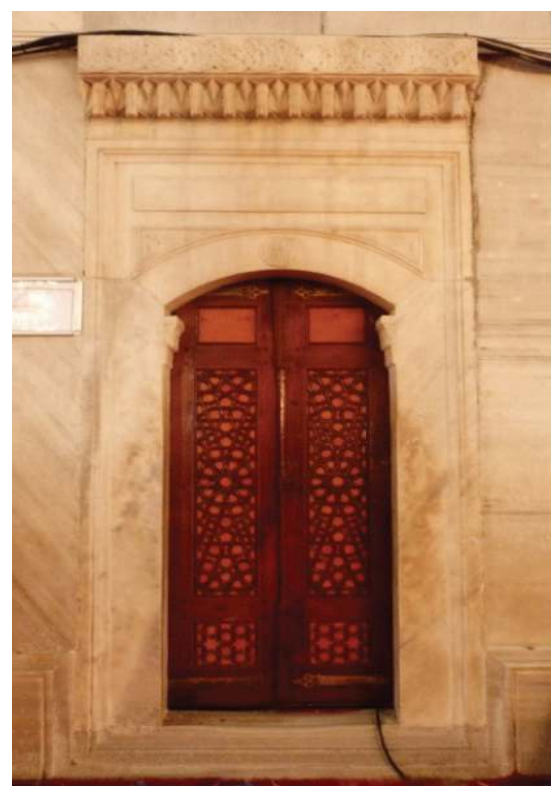

Ek 3: Üst mahfele çıkan kündekâri bir kapı ve kanatları

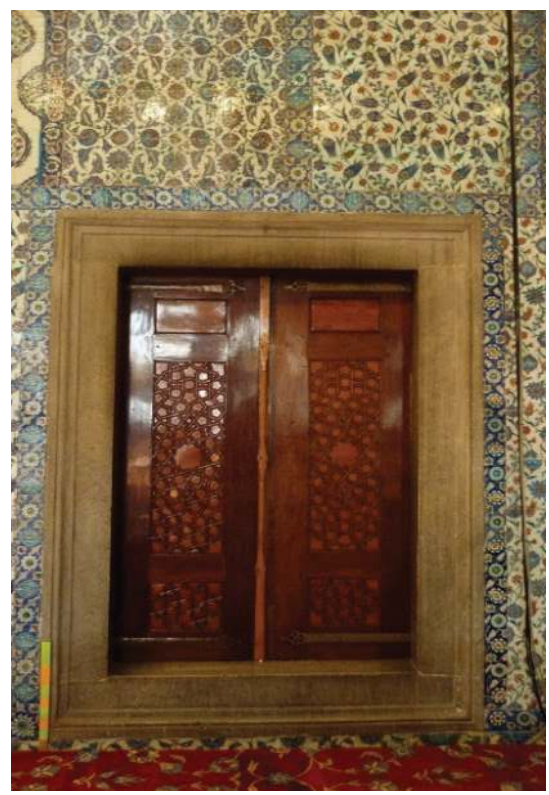

Ek 4: Üst mahfel kuzeybatı kündekârî pencerelerinden biri

Belleten, Nisan 2021, Cilt: 85/Sayı: 302; 53-94 


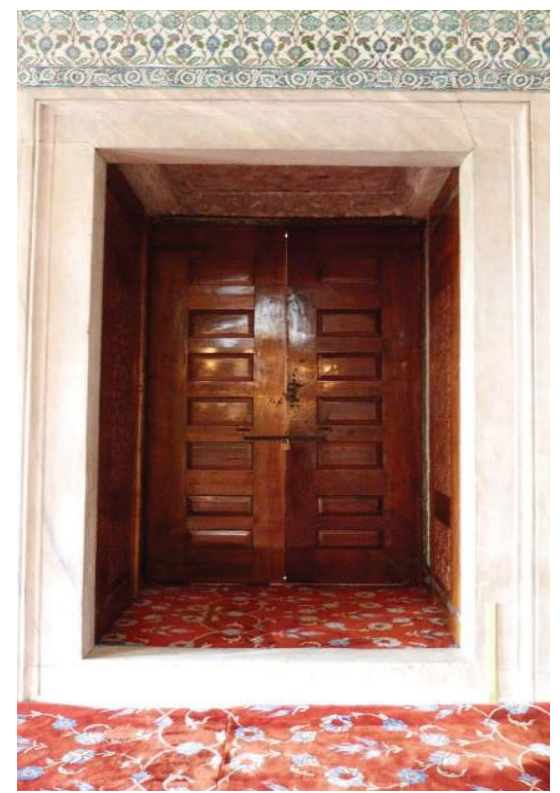

Ek 5: Sultan Ahmed Camii avlu pencerelerinden biri ve kündekârî kanatları.

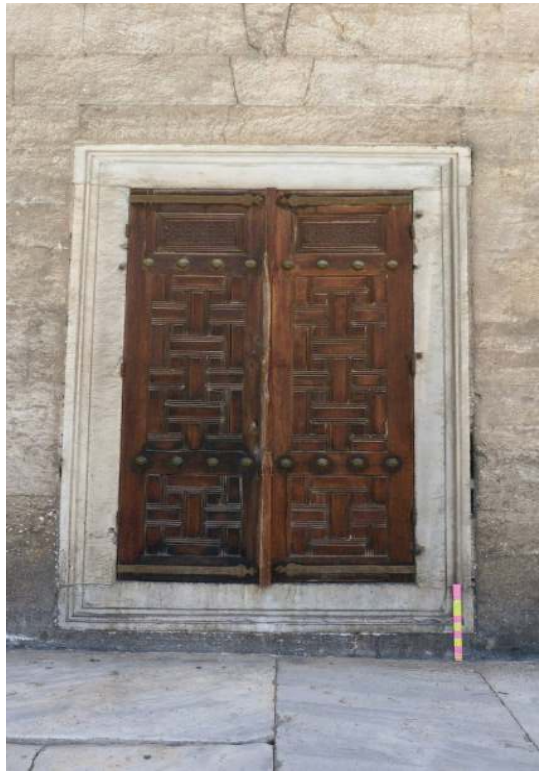

Ek 6: Sağdaki Sultan Ahmed Camii imam kapısı ve kanatları.

Belleten, Nisan 2021, Cilt: 85/Sayı: 302; 53-94 
Sultan Ahmed Külliyesi’nde Ahşap Malzeme Kullanımı

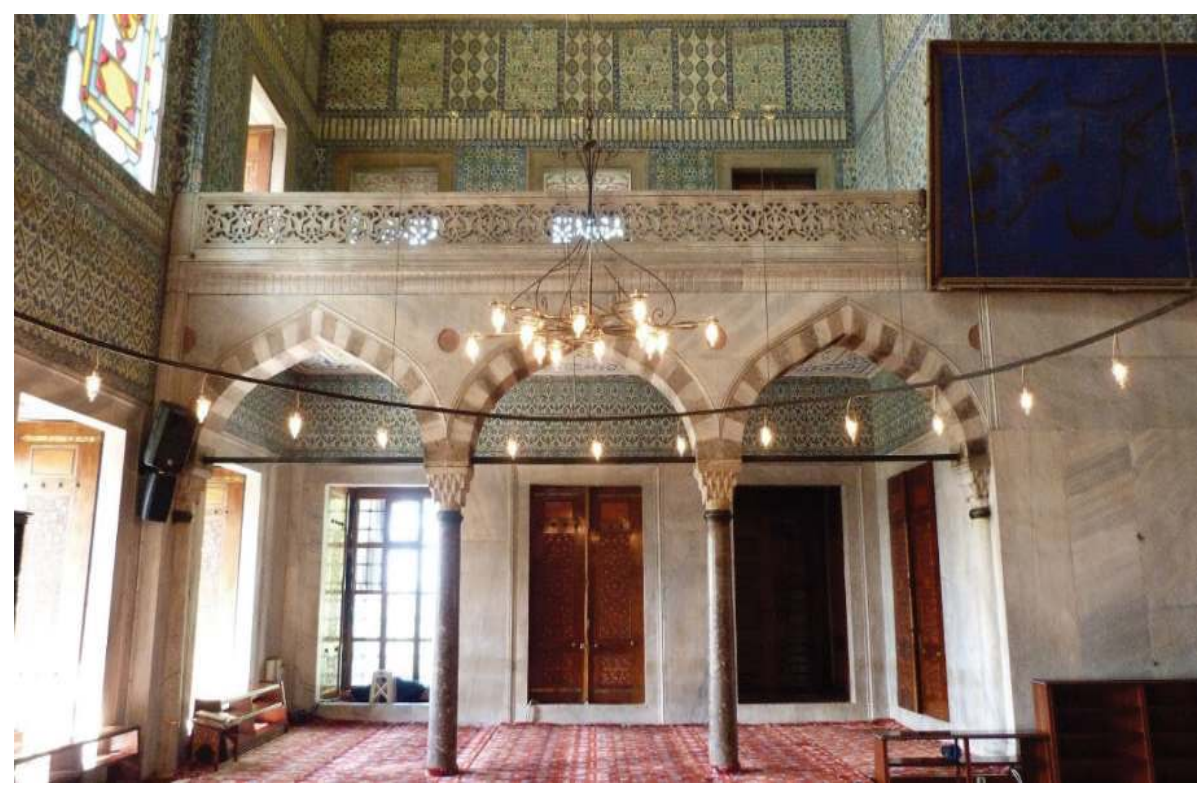

Ek 7: Sultan Ahmed Camii alt kat nizami pencereleri ve imam kapisinın genel görünümü. 


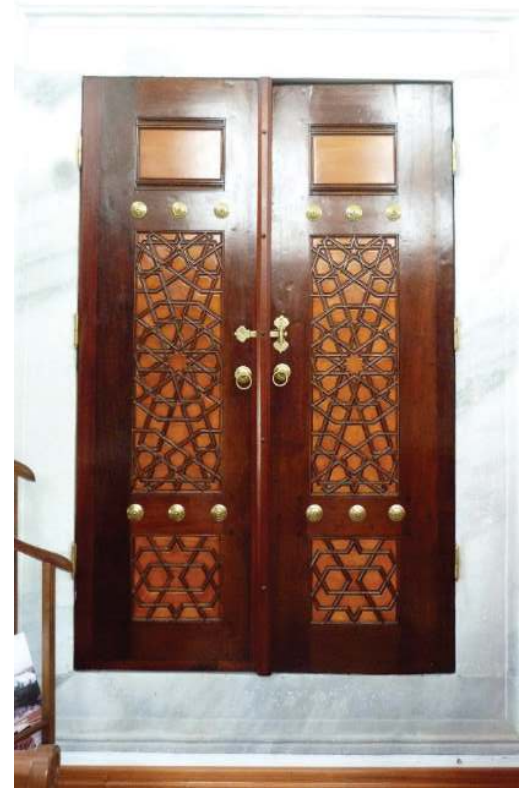

Ek 8: Sultan Ahmed Darülhadisi penceresi ve kündekârî kanatları

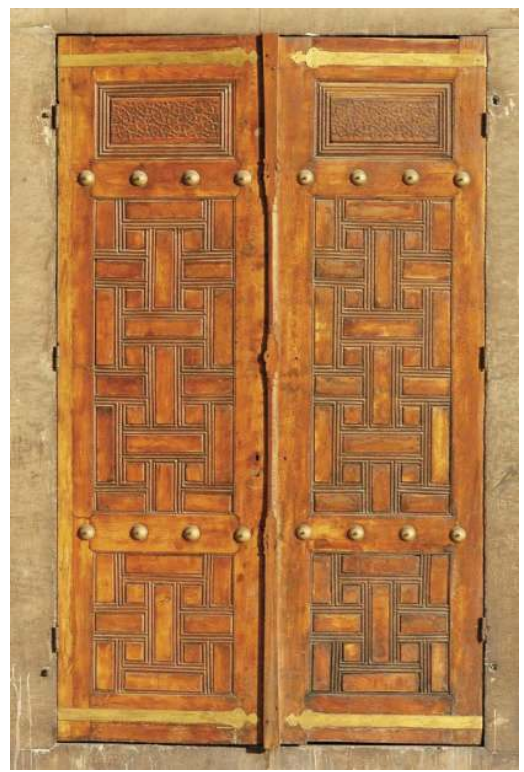

Ek 9: Sultan Ahmed Camii avlu pencerelerinden biri ve kündekâri kanatları 


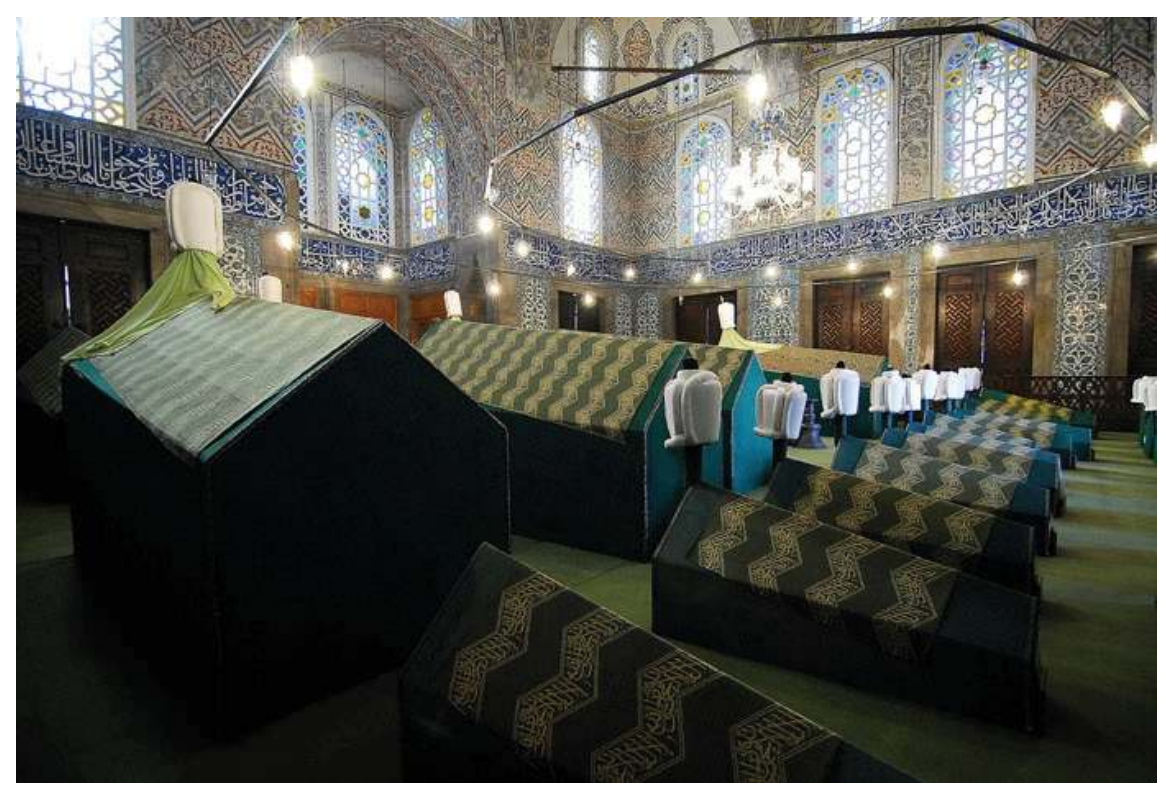

Ek 10: Sultan Ahmed Türbesi ve nizami pencereleri kündekârî kanatları genel görünümü.

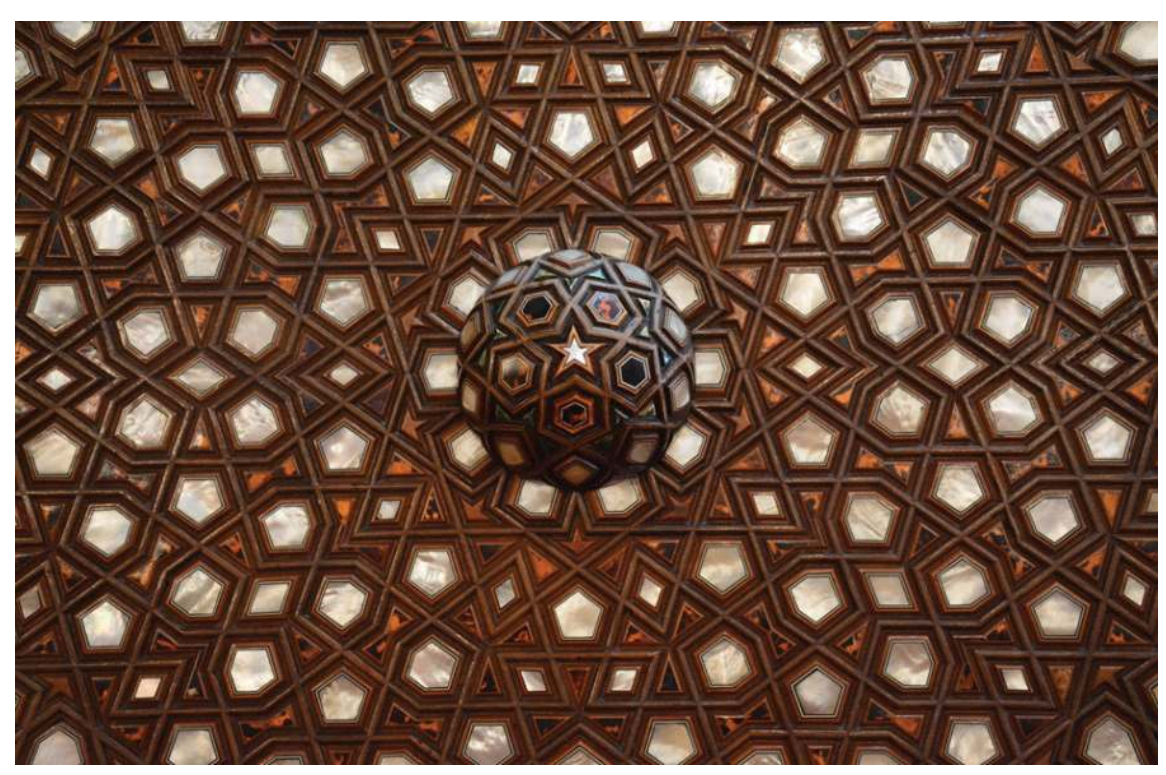

Ek 11: Sultan Ahmed Camii kündekârî vaaz kürsüsü detayı. 


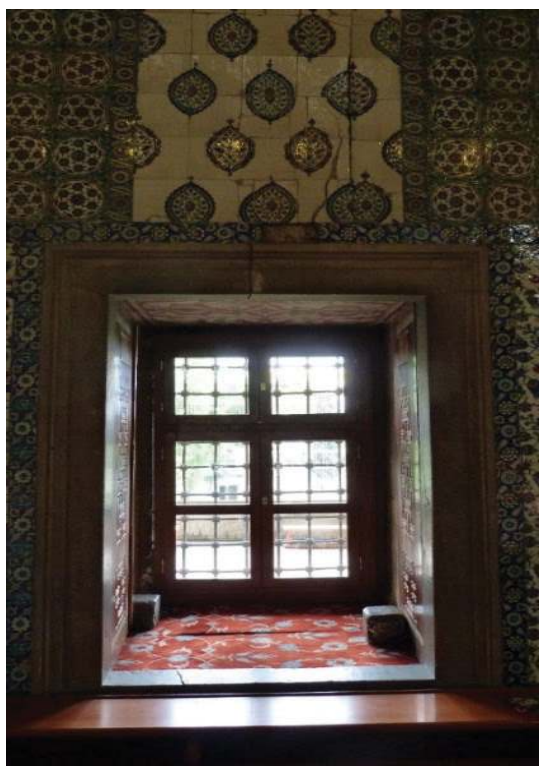

Ek 12: Sultan Ahmed Camii üst mahfel pencere kasaları.

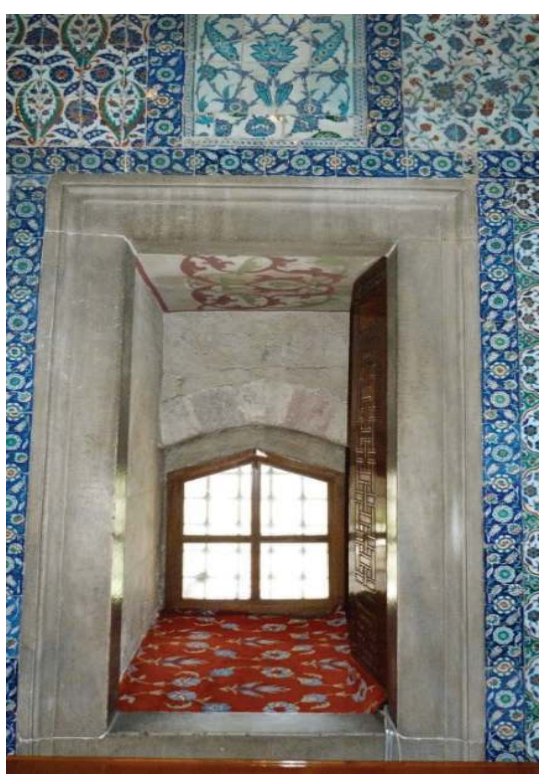

Ek 13: Sultan Ahmed Camii üst mahfel pencere kasaları.

Belleten, Nisan 2021, Cilt: 85/Sayı: 302; 53-94 